\title{
Petrography, geochemistry and geochronology of granite hosted rhyodacites associated with a disseminated pyrite mineralization (Arnolz, Southern Bohemian Massif, Austria)
}

\author{
Richard Göd $^{1}$ (D) • Johannes Kurzweil ${ }^{2} \cdot$ Urs Klötzli $^{1}$
}

Received: 18 April 2016 / Accepted: 8 September 2016 / Published online: 22 September 2016

(C) The Author(s) 2016. This article is published with open access at Springerlink.com

\begin{abstract}
The study focuses on a subvolcanic rhyodacite dyke intruding a fine grained biotite granite and paragneisses of the South Bohemian Massif, part of the Variscan Orogenic Belt in Central Europe. The subvertical dyke strikes NNE, displays a thickness of about $30 \mathrm{~m}$ and has been traced by boulder mapping for approximately $7 \mathrm{~km}$. The rhyodacites have been affected by two hydrothermal fluids. An older one of oxidizing condition giving rise to a reddish to brownish type of rock (Type I) and a younger fluid of reducing condition causing a greenish variety (Type II). The hydrothermal alteration is associated with the formation of the clay minerals chlorite, sericite, kaolinite and smectite and a disseminated pyrite mineralization. Bulk chemistries of the rhyodacites emphasize the hydrothermal alterations to be isochemical with the exception of sulphur enriched up to a maximum of $0.6 \mathrm{wt} \%$. Trace element composition of the rhyodacites points to a barren geochemical environment in terms of base and precious elements. Sulphur isotope investigations of pyrites from the rhyodacites and the hosting granites respectively
\end{abstract}

Editorial handling: J. G. Raith

Richard Göd

richard.goed@univie.ac.at

Johannes Kurzweil

johannes.kurzweil@univie.ac.at

Urs Klötzli

urs.kloetzli@univie.ac.at

1 Department of Lithospheric Research, University of Vienna, Althanstrasse 14, A - 1090 Vienna, Austria

2 Department of Geodynamics and Sedimentology, Althanstrasse 14, A - 1090 Vienna, Austria yield $\mathrm{d}^{34} \mathrm{~S}$ data ranging from +0.07 to $-2.22 \%$, emphasizing a magmatic origin of the sulphur. Geochronological investigations yield in situ $\mathrm{U} / \mathrm{Pb}$ zircon ages of $312 \pm 4 \mathrm{Ma}$ for the biotite granite and of $292 \pm 4$ Ma for the rhyodacitic dykes indicating a time gap of $\approx 20$ Ma between these two intrusive events. A contemporaneous but geochemically specialized granitic intrusion associated with NW striking "felsitic" dykes occurs about 10 to $20 \mathrm{~km}$ to the NW of Arnolz. However, the rhyodacites around Arnolz differ significantly from these felsitic dykes in their geochemistry and alteration phenomena which points to a different magmatic source. This coincides with a change in the orientation of the dykes from a NW direction controlling the geochemically specialized intrusions in the NW to a dominating NNE direction mirrored by the studied rhyodacites at Arnolz.

Keywords Subvolcanic rhyodacites · Disseminated pyrite mineralization · Southern Bohemian Massif

\section{Introduction}

During an exploration campaign covering the Austrian part of the Bohemian Massif a so far unknown rhyodacitic lithology was discovered. The dyke-like rhyodacites are hosted by a fine grained biotite granite and paragneisses and are associated with hydrothermal alteration phenomena characterized by the formation of clay minerals and a disseminated pyrite mineralisation respectively. A first report has been published by Göd et al. (2015). The present paper aims to document and describe this discovery with emphasis on its geological set up, petrography, geochemistry, the geochronology and associated alteration phenomena. 


\section{Geology}

\section{Regional geology}

The area of Arnolz is located within the Moldanubicum, part of the Variscan Bohemian Massif. The geology in the area of interest is characterized by Carboniferous granitic intrusions belonging to the so called "South Bohemian Pluton"and Precambrian paragneisses. Three main types of granites are distinguished: the coarse grained "Weinsberg" biotite granite, the medium to fine grained "Mauthausen" biotite granite and the medium grained "Eisgarn" two-mica granite, displaying ages between ca. $335 \mathrm{Ma}$ and $300 \mathrm{Ma}$, respectively (i.a. Klomínský et al. 2010b). Field relations strongly emphasize the Weinsberg type granite to be the oldest, followed by the Mauthausen type granite and finally the Eisgarn type granite. All three main types are by no means homogeneous and are composed of various subtypes (Vellmer and Wedepohl 1994; Koller 1994; Friedl 1997; Breiter 1998, 2010; Breiter and Scharbert 1996; Finger et al. 2007), giving rise to varying age data which are still a matter of discussion (Gerdes et al. 2003; Klomínský et al. 2010a, b).

Numerous felsitic, "porphyritic dykes" (Waldmann 1950), predominantly striking NW-SE to N-S, characterize the immediate geology $\mathrm{W}$ and $\mathrm{N}$ of the area under investigation (Fig. 1). Of particular interest are NW to $\mathrm{N}$ striking dykes extending approximately from Litschau (Austria) to Lásenice (Czech Republic) for a distance of about $20 \mathrm{~km}$ (Klećka and Vaňková 1988; Vrána 1990; Breiter and Scharbert 1995; Breiter 1998). A completely different kind of dykes striking $\mathrm{N}$ to NNE close to the village of Arnolz (Figs. 1 and 2) are the focus of the present paper.

\section{Local geology}

The local geology is dominated by NNE-SSW striking structures mirrored by the geometry of the local granitic bodies (Fig. 2). This structure is of regional significance and extends to the $\mathrm{S}$ and $\mathrm{N}$ exceeding the area under discussion. Two rock types dominate: firstly, monotonous, cordierite bearing paragneisses of Precambrian age. These uniformly looking rocks belong to the so called "Monotonous Series", one of the major tectono-lithological units within the Moldanubicum. Secondly, a fine grained biotite granite occurs. This is described as Mauthausen-type granite by Waldmann (1950), a classification most possibly outdated, as no recent investigation has been carried out. A third lithology is denoted on the geological map (Waldmann 1950) as isolated "porphyritic" boulders, scattered across the map sheet and as "porphyritic", N-S trending dikes around and NW of Pfaffenschlag (Fig. 2). Following observations in the quarry Arnolz (see below), detailed boulder mapping proved porphyritic rhyodacitic boulders to occur for not less than $7 \mathrm{~km}$, closely following the general NNE-SSW strike. It has to be emphasized, that the boulders are equally distributed within areas of granites and paragneisses, indicating that the porphyritic rocks intruded granites and paragneisses alike.

\section{The quarry „Arnolz“}

The quarry Arnolz (Fig. 3) is located some $4 \mathrm{~km} \mathrm{NW}$ of the village Arnolz (Figs. 1 and 2). The face of the quarry, approximately $100 \mathrm{~m}$ wide and around $20 \mathrm{~m}$ high, is characterized by a fine grained biotite granite to the $\mathrm{E}$ and $\mathrm{W}$ and a rhyodacitic (sub)- volcanic dyke in its centre. The biotite granite grades into a two mica granite and a muscovite granite, respectively, towards the rhyolitic dyke. The subvertical dyke is ca. $30 \mathrm{~m}$ thick and strikes NNE with $10^{\circ}$ to $15^{\circ}$. A prominent, obviously reactivated fault of the same direction forms its western contact to the granite whereas its eastern contact is less pronounced but also structurally controlled. The rhyodacite tends to become coarser grained close to the contacts with the host granite. The dyke is hydrothermally altered to various degrees (see below). To the easternmost end of the quarry a second and coarse grained rhyodacite indicates the presence of a second dyke continuing underneath the overburden. Close to the E base of the quarry, an irregularly shaped paragneiss xenolith occurs within the granite and is itself crosscut by a granitic dyke of $\approx 1 \mathrm{~m}$ width (Fig. 3). This paragneiss xenolith belongs to the surrounding Monotonous Series as described.

The rhyodacites are characterized by a medium to locally coarse grained volcanic texture without any preferred textural orientation (minor exceptions are described below). They display a variety of phenotypes irregularly distributed across the quarry. Basically, two major phenotypes can be distinguished: a reddish to brownish and a greenish variety, thereafter termed as "Type I" and "Type II", respectively. The reddish/brownish variety (Type I) is characterized by idio- to hypidiomorphic plagioclase and quartz phenocrysts within an extremely fine grained, cloudy matrix of reddish to brownish colour. Plagioclase crystals may reach a maximum size of ca. $10 \mathrm{~mm}$, quartz crystals the size of ca. $5 \mathrm{~mm}$. The colour of the matrix varies between slightly reddish to a brick-like, deep-red-brown shade (Fig. 4a-d). The plagioclase crystals are generally altered and vary in colour between milky white to slightly yellow to reddish. They tend to form clusters. Needle -shaped amphibole crystals locally up to $1 \mathrm{~cm}$ in size (Fig. 4c) as well as small biotite crystals (some mm) are macroscopically hardly discernible. However, biotite and amphibole contribute to less than 5 vol. $\%$ to the whole rock and may, locally, even be absent. Both minerals are intensively chloritized. No potassium feldspar can be recognized macroscopically. While the contacts between the hosting granite and the volcanic rocks are sharp, the latter tend to become coarser 
Fig. 1 Regional Distribution of felsic dykes in the area of investigation. The dykes intrude all three main types of granites comprising the South Bohemian Pluton and the surrounding paragneisses ("Monotonous Series") respectively. Note the different orientations of the dykes. The sketch is based on the geological map by Waldmann (1950), sheet 4454, 1:75000,

Geol.B-A, Vienna and the sheets 1:50 000 33-11, A Malecha, 1988; 33-12 J Hron, V Jenćek, O Holásek, 1990; 23-33 A Malecha, 1990; 23-34 J Hron, P Hradecký,

O Holasek, 1991, all Czech

Geological Survey, Prague, redrawn and simplified from Schnabel et al. (2002)

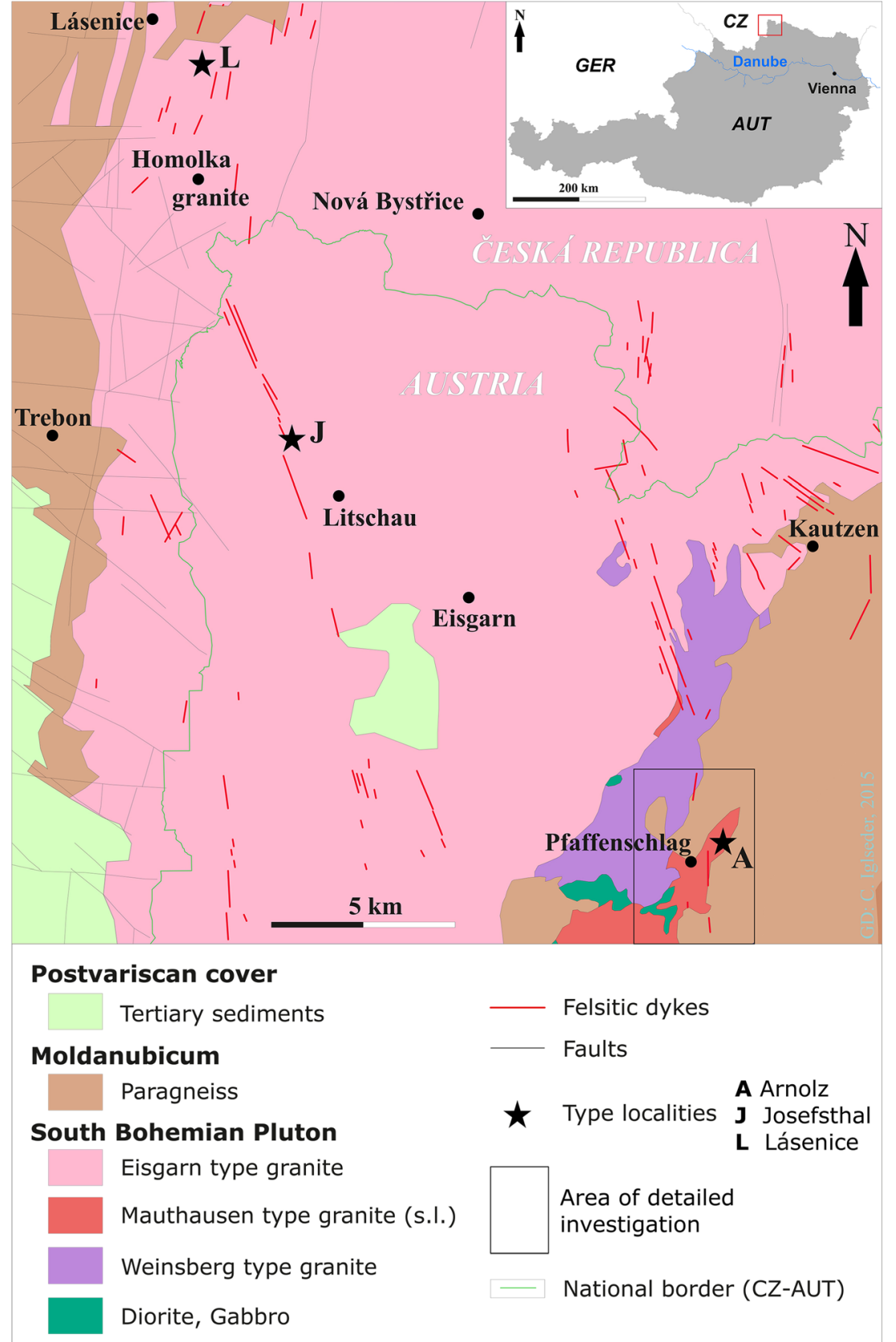

grained with increasing vicinity to the contacts. The greenish variety (Type II, Fig. 5e-d) is identical to Type I in terms of its texture and mineralogy. Plagioclase crystals are cloudy caused by sericitization frequently reflecting their slight zonation. Locally, vague signs of fluidal textures are visible (Figs. $4 \mathrm{e}$ and 5f). The contacts between Type I and Type II may be sharp but locally also gradational and are possibly best described as "front-like". Progressing alteration of Type II rocks may give rise to an overall fine grained type of rock of more/less whitish colour with the plagioclases to become almost invisible. These rocks have been found only as isolated, single blocks in the rock fall material and cannot be located within the quarry at present (AR 10, AR 11; Fig. 3). Disregarding the colour, Type I and Type II display identical microscopic features. Plagioclases are idio - to hypidiomorphic frequently forming clusters (Fig. 5c) and are completely sericitized. Twinning and a possible zoning is - if ever - indicated only very vaguely (Fig. 5e). Single plagioclase crystals seem to "fade away" with increasing alteration (Fig. 5f) while the rock looses gradually its volcanic texture. Potassium feldspars were generally not observed microscopically due to their extremely small grain size. Idiomorphic to hypidiomorphic hornblende and biotite crystals are largely chloritized and nevertheless easy to recognize based on their 
Fig. 2 Regional geology and results of boulder mapping around the quarry Arnolz. The distance between the northernmost and southernmost heavily weathered porphyritic boulders is ca. $7 \mathrm{~km}$; as shown, these boulders are equally distributed within granitic and gneissic host rocks emphasizing emplacement of the dykes into both lithologies. The northernmost boulder displays a disseminated pyrite mineralization equally to the one displayed in the quarry. The lack of mineralization in other boulders is most likely due to their intensive weathering. The boulders seem to be aligned roughly along a NNE-SSW direction which corresponds to observations in the quarry

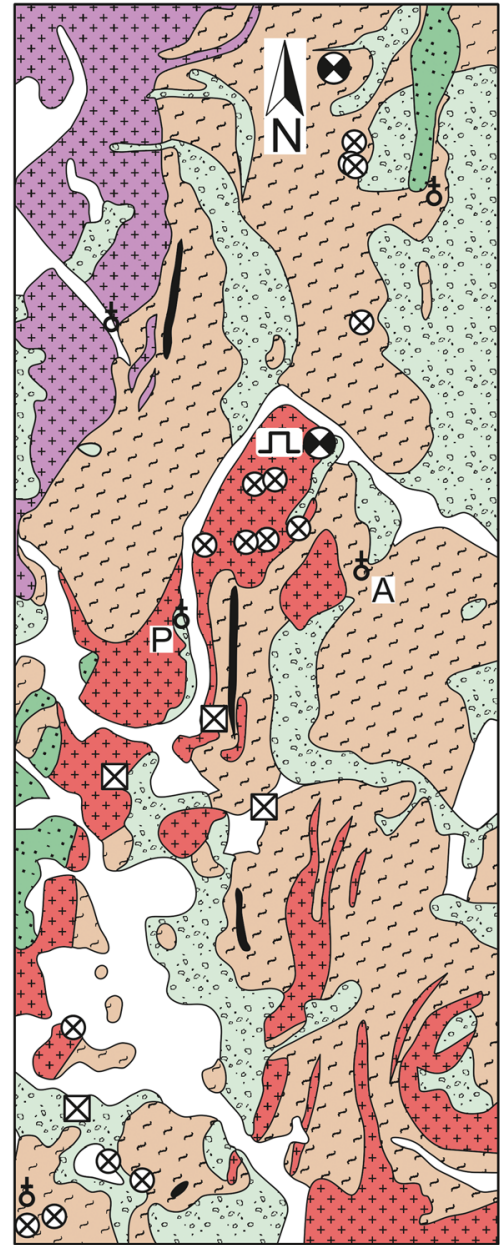

Alluvium

Tertiary sediments

(clay, sand, conglomerates)

Biotite granites, finegrained (Mauthausen type granite)

Weinsberg type granite

Paragneisses, cordierite bearing

Diorites

$\square$ Porphyritic dykes

$几$ Quarry Arnolz

\& Porphyritic boulders, autochthonous

pyrite bearing

$\bigotimes \quad$ Porphyritic boulders, sub-autochthonous

P Pfaffenschlag

A Arnolz

$\begin{array}{lll}0 & 2 & 3 \mathrm{~km}\end{array}$ morphology (Fig. 5d). The matrix is extremely fine grained and cloudy with grain sizes well below $100 \mu \mathrm{m}$ and even down to some microns. Minor indications of fluidal textures have been observed in rare, single specimens (Fig. 5f). These

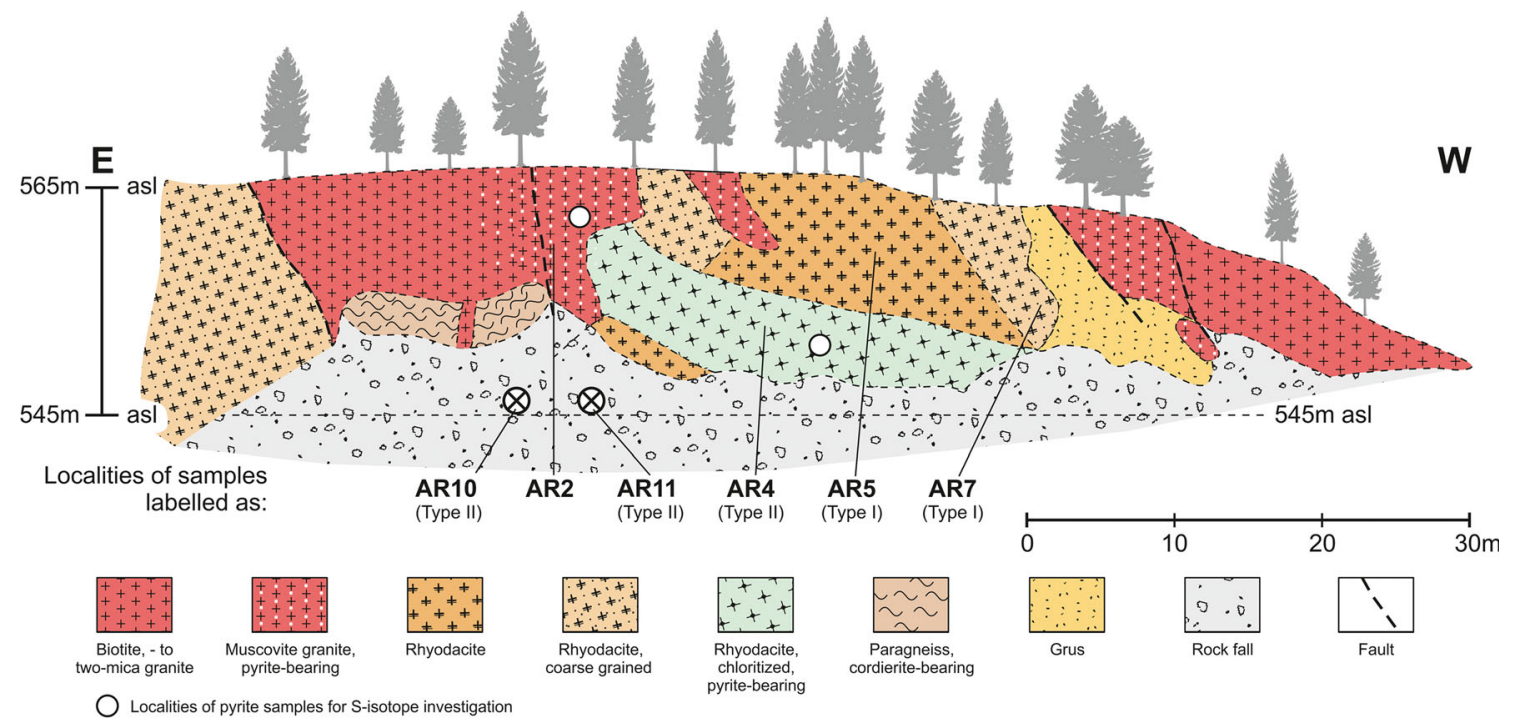

Fig. 3 Quarry Arnolz, status: autumn 2014; the contact between AR5 (Type I) and AR4 (Type II) might be sharp and also gradational ("front like"). Sample AR 10 and AR 11 are taken from the rock fall and cannot be located within the face; note the paragneiss xenolith close to the lower E crosscut by a granite dyke 
Fig. 4 Macroscopic phenotypes of rhyolites: (i) photos a-d refer to Type I samples, characterized by their reddish to brownish colour and their whitish, cloudy porphyritic plagioclases, locally forming clusters. Needle like hornblende crystals (picture c) may locally reach cm-size; the small, dark-greenish nodule to the right size in (a) is composed of chloritized biotite, chlorite, chloritized hornblende, sphene and opaque phases. Nodules of that composition may reach sizes up to $10 \mathrm{~cm}$. (ii) photos (e, f) refer to Type II samples, characterized by their overall greenish colour; however, their texture does not differ from the textures of Type I samples. Note the slight inhomogeneity in grain size in (e) which points to some kind of primary flow structure (see also Fig. 5)
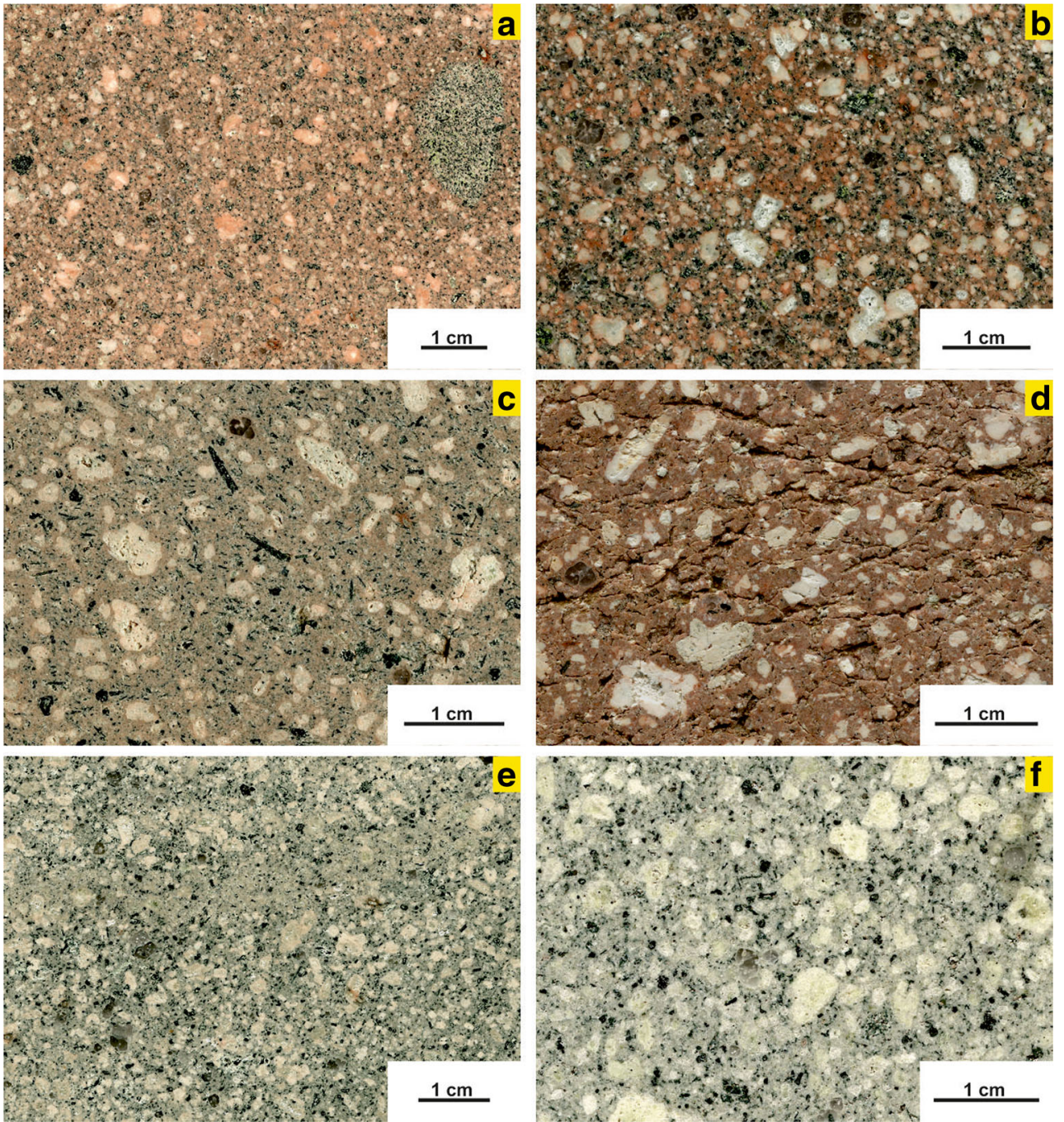

fine grained samples, not of porphyritic texture anymore, belong to the Type II volcanic rocks. Relictic glass has not been detected.

Occasionally, circular to egg-shaped, dark-green inclusions up to $\approx 10 \mathrm{~cm}$ in size can be observed within the rhyodacites. These inclusions are enriched in chlorite, chloritized biotites and hornblendes and, rarely, in pyrite. They are interpreted as "basic nodules" and do not represent xenoliths sensu stricto.

The biotite granite displays a fine grained, homogeneous, equigranular texture without any extraordinary features. As mentioned and according to Waldmann (1950), it belongs to the "Mauthausen type granite", one of the main granitic intrusive suites within the South Bohemian Pluton. With increasing proximity to the rhyolites, the granite turns gradually into a muscovite granite mineralized with pyrite which forms a "pyrite halo" extending some 5 to $10 \mathrm{~m}$ into the granite (see below). Weathering may give rise to a stained, spotted appearance and a soft type of rock easy to split manually. Thin sections reveal the texture and mineralogical composition of a fine grained locally to some extent altered biotite granite.
Plagioclase is sericitized to varying degrees, microclines is perthitic and biotite is partially chloritized. Secondary muscovite is present towards the contact with the rhyodacites. Apatite and rare zircons are common accessories.

The paragneiss xenolith is a dark-grey, black spotted, schistose rock with sharp contacts to the surrounding granite. Locally, slickensides within the paragneiss are coated with pyrite. The xenolith itself is crosscut by a granitic dyke of around $1 \mathrm{~m}$ thickness and belongs, without any doubt, to the surrounding paragneisses of the Monotonous Series. Thin sections frequently display sericitic agglomerates, interpreted as pseudomorphs after cordierite in analogy to the regionally occurring cordierite-bearing paragneisses. The pseudomorphs themselves form $\mathrm{cm}$-sized nodules causing the macroscopically spotted appearance of the rock. Quartz, slightly sericitized plagioclases, rare potassium feldspar, chloritized biotites and some minor muscovite are additional constituents.

The disseminated pyrite mineralization is strictly related to Type II volcanics. Pyrite occurs as hypidio - to idiomorphic crystals forming cubes of $\leq 0.5 \mathrm{~mm}$ in size. Its modal content 
Fig. 5 Microscopic textures of rhyolites (a, b corresponding to Type I, c-f to Type II) displaying text book like volcanic textures characterized by an extremely fine grained, cloudy matrix not resolvable by microscopic observation (a, b), idiomorphic (c) quartz crystals with embayment structures (d), idiomorphic hornblende crystals (d) and hypidiomorphic, fully sericitized, zoned plagioclases (e). Fluidal texture is shown in (f)
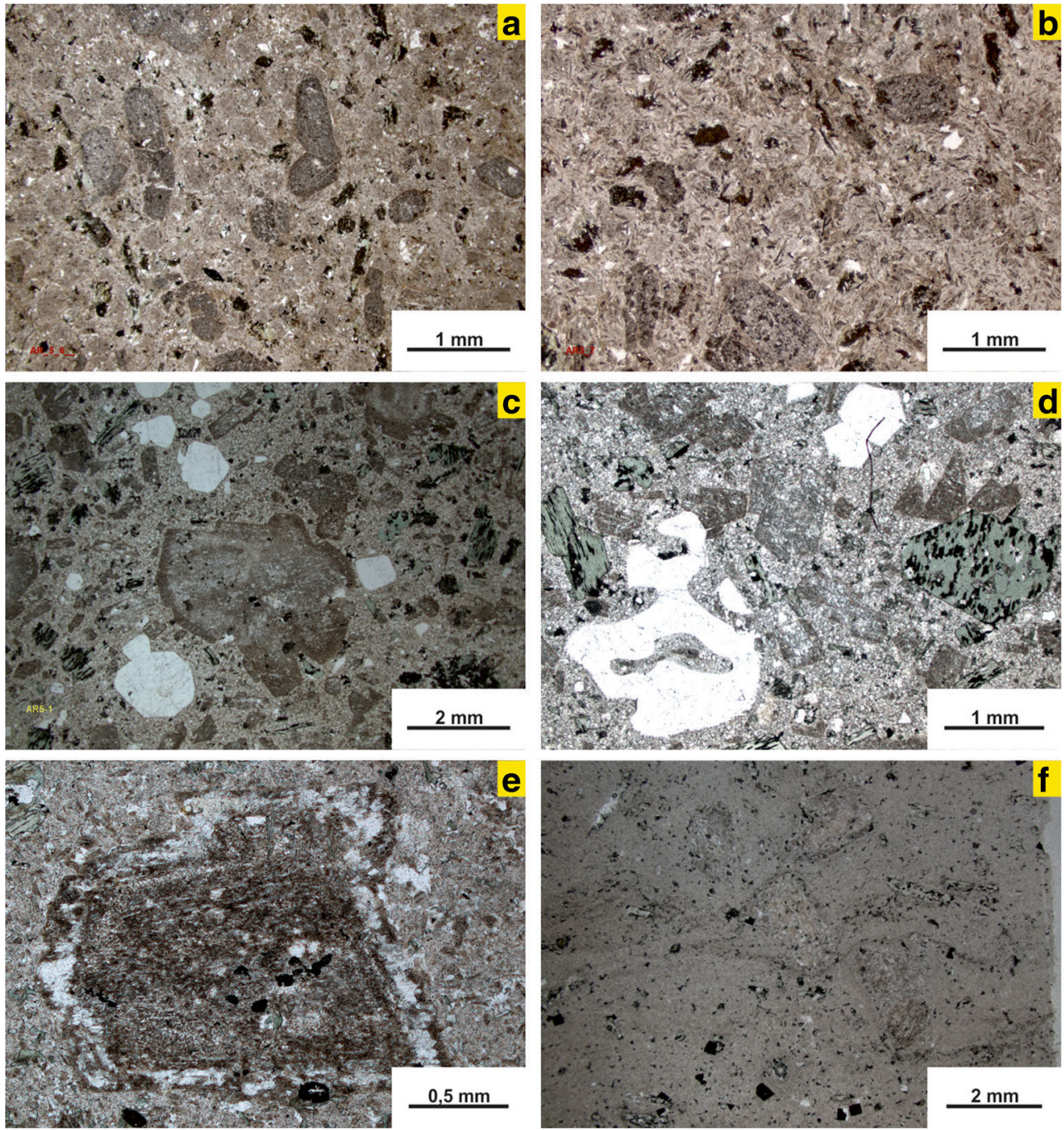

does generally not exceed 1 vol\%. Reflected light microscopy reveals homogeneous distribution within the matrix and its small grain sizes even as small as a few micrometers. Pyrite is not associated with quartz veinlets or any kind of quartz enrichment and it is more/less evenly distributed within the matrix. The highest pyrite is found in samples AR 10 and AR 11 - in accordance with their higher sulphur content (Table 1). Pyrite mineralizations have been found within the quarry and, additionally, in one single boulder farthest to the north (Fig. 2) suggesting a possible extension of the mineralization for at least $3 \mathrm{~km}$. However, due to the strong weathering of all the boulders mapped it is assumed that the pyrite mineralization occurs over the whole distance of the dyke(s) as indicated by the mapping (Fig. 2). The pyrite mineralization in granites occurs approximately within 5 - to $10 \mathrm{~m}$ from the contact to the volcanic rocks and decreases rapidly with distance from the latter. Pyrite in granites is coarser grained than in the volcanic rocks and may form cubes of some $\mathrm{mm}$ in size, coating cleavages in granite fissures close to the contact. This kind of mineralization gives rise to a "pyritic halo" within the granite and does not display the character of a disseminated mineralization per se. A weak chloritization of the fissures and cleavages is associated with the pyrite mineralization.

\section{Sampling and analytical methods}

A total of fifty five thin sections have been prepared for transmitted light microscopy and six polished sections for reflected light microscopy. Additional 4 samples have been prepared for electron microprobe analyses, two samples for S-isotope investigations and one sample for producing a heavy mineral concentrate. A total of sixteen rhyodacite and three granite samples has been taken across the quarry for bulk and trace element whole rock analyses. Sample masses for chemical analyses where generally around three $\mathrm{kg}$ each. The samples where communited via jaw crusher, split and ground using an agate mill. The element analyses were performed on a sequential X-Ray spectrometer PHILIPS PW2404 using a super-sharp end- 
Table 1 Whole rock major (mass\%) and trace element ( $\mathrm{ppm}$ ) data of granite and rhyodacites from the quarry Arnolz; AR $2=$ granite samples; AR 5 and AR 7 = Type I rhyodacites; AR 4, AR 10 and AR 11 = Type II rhyodacites; J = felsitic dykes around Josefsthal (Breiter 1998); L= felsitic dykes around Lásenice (Klećka and Vaňková 1988); data of Homolka granite according to Breiter and Scharbert (1995)

\begin{tabular}{|c|c|c|c|c|c|c|c|c|c|}
\hline & \multirow{3}{*}{$\begin{array}{l}\text { ARNOLZ } \\
\text { GRANITE } \\
\text { AR } 2 \\
n=3\end{array}$} & \multicolumn{7}{|c|}{ VOLCANICS } & \multirow{3}{*}{$\begin{array}{l}\text { HOMOLKA } \\
\text { GRANITE } \\
n=4\end{array}$} \\
\hline & & \multicolumn{2}{|c|}{ Type I } & \multicolumn{3}{|c|}{ Type II } & \multirow{2}{*}{$\begin{array}{l}\mathrm{J} \\
n=3\end{array}$} & \multirow{2}{*}{$\begin{array}{l}\mathrm{L} \\
n=8\end{array}$} & \\
\hline & & $\begin{array}{l}\text { AR } 5 \\
n=5\end{array}$ & $\begin{array}{l}\text { AR } 7 \\
n=2\end{array}$ & $\begin{array}{l}\mathrm{AR} 4 \\
n=6\end{array}$ & $\begin{array}{l}\text { AR } 10 \\
n=2\end{array}$ & $\begin{array}{l}\text { AR } 11 \\
n=1\end{array}$ & & & \\
\hline $\mathrm{SiO}_{2}$ & 74.29 & 68.53 & 70.41 & 69.10 & 68.65 & 69.57 & 73.21 & 73.30 & 73.11 \\
\hline $\mathrm{TiO}_{2}$ & 0.24 & 0.54 & 0.57 & 0.51 & 0.62 & 0.66 & 0.031 & 0.013 & 0.03 \\
\hline $\mathrm{Al}_{2} \mathrm{O}_{3}$ & 14.20 & 16.13 & 16.75 & 16.07 & 16.30 & 17.05 & 14.30 & 14.61 & 15.04 \\
\hline $\mathrm{Fe}_{2} \mathrm{O}_{3}$ & 1.27 & 2.91 & 1.79 & 2.84 & 3.27 & 1.71 & 1.06 & 1.74 & 0.66 \\
\hline $\mathrm{MnO}$ & 0.01 & 0.04 & 0.01 & 0.04 & 0.05 & 0.01 & 0.04 & 0.04 & 0.08 \\
\hline $\mathrm{MgO}$ & 0.25 & 1.19 & 0.26 & 1.10 & 1.37 & 0.39 & 0.05 & 0.18 & 0.05 \\
\hline $\mathrm{CaO}$ & 0.30 & 1.42 & 0.71 & 0.66 & 0.84 & 1.03 & 0.53 & 0.52 & 0.52 \\
\hline $\mathrm{Na}_{2} \mathrm{O}$ & 2.96 & 4.86 & 4.72 & 4.60 & 3.80 & 3.35 & 4.12 & 3.76 & 4.49 \\
\hline $\mathrm{K}_{2} \mathrm{O}$ & 5.34 & 3.20 & 3.38 & 3.61 & 4.12 & 4.54 & 3.83 & 4.64 & 3.72 \\
\hline $\mathrm{P}_{2} \mathrm{O}_{5}$ & 0.20 & 0.17 & 0.18 & 0.17 & 0.22 & 0.23 & 0.49 & 0.44 & 0.67 \\
\hline $\mathrm{S}$ & 0.20 & 0.05 & 0.01 & 0.25 & 0.51 & 0.60 & na & na & - \\
\hline LOI & 0.28 & 0.37 & 0.45 & 0.45 & 0.65 & 0.80 & na & 0.79 & - \\
\hline $\mathrm{S}=\mathrm{O}$ & -0.30 & -0.07 & -0.01 & -0.37 & -0.76 & -0.90 & na & na & - \\
\hline Total & 99.54 & 99.41 & 99.24 & 99.61 & 100.40 & 99.94 & 97.66 & 100.02 & 98.37 \\
\hline $\mathrm{F}$ & 490 & 456 & 360 & 500 & 670 & 460 & 3860 & 1280 & 3710 \\
\hline $\mathrm{Ba}$ & 470 & 430 & 495 & 410 & 463 & 665 & na & 129 & - \\
\hline $\mathrm{Rb}$ & 244 & 79 & 87 & 100 & 142 & 145 & 519 & 482 & 1067 \\
\hline $\mathrm{Sr}$ & 90 & 596 & 502 & 415 & 346 & 646 & $15^{*)}$ & 47 & 28 \\
\hline $\mathrm{La}$ & 30 & 26 & 31 & 24 & 30 & 20 & 5 & na & 1.7 \\
\hline $\mathrm{Ce}$ & 64 & 55 & 48 & 52 & 61 & 45 & 11 & na & 4.9 \\
\hline Y & 7 & 9 & 10 & 9 & 12 & 11 & na & 7 & - \\
\hline As & 2.5 & 0.2 & 0.2 & 0.9 & 1.5 & 0.2 & 0.5 & 3 & 4 \\
\hline $\mathrm{Pb}$ & 30 & 9 & 8 & 6 & 7 & 9 & $14^{*)}$ & na & 6 \\
\hline $\mathrm{Zn}$ & 115 & 63 & 94 & 52 & 62 & 38 & 45 & 68 & 87 \\
\hline $\mathrm{Cu}$ & 12 & 6 & 7 & 7 & 6 & 4 & na & 5.6 & - \\
\hline Mo & 1 & 1 & 1 & 1 & 1 & 1 & na & 1 & - \\
\hline $\mathrm{Ag}$ & 1 & 1 & 1 & 1 & 1 & 1 & na & na & - \\
\hline $\mathrm{Au}(\mathrm{ppb})$ & 5 & 5 & 5 & 5 & 5 & 5 & na & na & - \\
\hline Cs & 4.3 & 2.4 & 2.5 & 1.6 & 2.6 & 3.4 & 33 & $56 * *)$ & 71 \\
\hline $\mathrm{Li}$ & 10 & 25 & 7 & 21 & 28 & 18 & na & 107 & - \\
\hline $\mathrm{Be}$ & 2.6 & 1.7 & 1.9 & 1.6 & 1.9 & 1.9 & na & $1.8^{* * *}$ & - \\
\hline $\mathrm{Sn}$ & 4 & 1 & 1 & 1 & 1 & 1 & 15 & 16 & 99 \\
\hline W & 19 & 5 & 2 & 7 & 4 & 2 & 4.2 & $10^{*)}$ & 10 \\
\hline $\mathrm{Nb}$ & 8 & 9 & 10 & 8 & 10 & 12 & na & 25 & 51 \\
\hline $\mathrm{Ta}$ & 0.7 & 0.6 & 0.7 & 0.7 & 0.7 & 0.8 & 6.9 & 20 & 24 \\
\hline Th & 26 & 6 & 6 & 6 & 6 & 6 & 3.7 & 6.3 & 1 \\
\hline $\mathrm{U}$ & 8 & 1 & 2 & 1 & 2 & 2 & 5.3 & 8.4 & 12.5 \\
\hline $\mathrm{Th} / \mathrm{U}$ & 3.2 & 6 & 6 & 6 & 3 & 3 & 0.7 & 0.75 & 0.08 \\
\hline $\mathrm{Zr}$ & 113 & 182 & 182 & 178 & 192 & 212 & 7 & 41 & $18^{* * * *)}$ \\
\hline $\mathrm{K} / \mathrm{Rb}$ & 181 & 336 & 322 & 300 & 241 & 260 & 61 & 106 & 26 \\
\hline $\mathrm{Rb} / \mathrm{Sr}$ & 2.7 & 0.13 & 0.17 & 0.24 & 0.41 & 0.22 & 35 & 10.2 & 38 \\
\hline
\end{tabular}

*) $n=2 ;{ }^{* *)} n=5 ;{ }^{* * *)} n=3$; na $=$ not analyzed

$\mathrm{J}=$ Josefsthal; $\mathrm{L}=$ Lásenice

window tube with a $\mathrm{Rh}$-anode and a programmable $4 \mathrm{~kW}$ generator (60 kV max., $125 \mathrm{~mA}$ max.; iso-Watt-switching), the accompanying software is PANalytical "SuperQ" vers. 5.1B (5.2822.3). Major elements were determined on calcined rock powder fused with lithium tetraborate as flux to form a glass bead. Trace elements were determined directly on the crushed and milled rock powder mixed with polyvinyl alcohol as a binding agent to form a pressed powder pellet. These analyses have been carried out at the Department of Lithospheric Research, University of Vienna. Trace elements demanding lower detection limits - exceeding XRF's capability - have been analysed by ALS Minerals (Ireland) using a four acid digestion followed by ICP-MS; fluorine has been analysed by $\mathrm{KOH}$-fusion and an ion selective electrode, total sulphur by Leco furnace and gold by fire assay followed by ICP-AES (30 g sample size). 
A heavy mineral concentrate was prepared from one rhyodacite sample of around $5 \mathrm{~kg}$ via shaking table followed by magnetic and heavy liquid separation respectively. The minerals where identified by their Raman spectra obtained by means of a dispersive Horiba LabRam HR 800 Evolution spectrometer. This system was equipped with Olympus BX41 optical microscope $(100 \times$ objective; numerical aperture 0.9$)$ and an Si-based, Peltier-cooled charge-coupled device (CCD) detector. With a diffraction grating with 1800 grooves $/ \mathrm{mm}$ placed in the beam path, the spectral resolution was between 0.8 (red excitation) and $1^{-1} \mathrm{~cm}$ (blue excitation). Depending on the respective grain's luminescence behaviour, spectra were excited with the $473 \mathrm{~nm}$ line of a diode laser or the $\mathrm{He}-\mathrm{Ne} 632.8 \mathrm{~nm}$ line $(8-10 \mathrm{~mW}$ at the sample surface). The lateral resolution was $\sim 1 \mu \mathrm{m}$. The samples were analysed at the Institute of Mineralogy and Crystallography at the University of Vienna.

To investigate the extremely fine grained matrix, obviously composed i.a. of clay minerals, four samples from various phenotypes have been selected for X-ray diffraction: samples AR5 and AR 7 representing Type I and samples AR 4 and AR 11 representing Type II volcanics respectively. All measurements have been carried out using a PANalytical X'Pert Pro diffractometer $(\mathrm{CuK} \alpha$ radiation, $40 \mathrm{kV}, 40 \mathrm{~mA}$, step size $=0,0167,5 \mathrm{~s}$ per step). The clay fraction $(<2 \mu \mathrm{m})$ of the two rock types were obtained according to Moore and Reynolds (1997). The suspension $(8 \mathrm{mg} / \mathrm{ml})$ gained was applied to glass slides, air dried and analysed. For further identification of clay minerals, DMSO-saturation of samples has been carried out. The X-ray diffraction patterns were evaluated according to the same authors.

Six pyrite samples have been analysed for their $\delta{ }^{34}$ S systematics. Three pyrite samples have been taken within the granite close to the sample AR 2 (Fig. 3), another three from Type II rhyolites across the face of the quarry (AR4, ibidem). After pre-concentrations of the crushed and sieved rock samples via shaking table and heavy liquid separation, the final lean pyrite concentrate was prepared manually by hand picking. Sulphur isotope analysis of the samples was undertaken by Iso-Analytical Ltd (UK) using Elemental Analysis-Isotope Ratio Mass Spectrometry (EA-IRMS). Tin capsules containing reference or sample material plus vanadium pentoxide catalyst were loaded into an automatic sampler. From where they were dropped, in sequence, into a furnace held at $1080{ }^{\circ} \mathrm{C}$ and combusted in the presence of oxygen. Tin capsules flash combust, raising the temperature in the region of the sample to $\sim 1700{ }^{\circ} \mathrm{C}$. The combusted gases are then swept in a helium stream over combustion catalysts (tungsten oxide/zirconium oxide) and through a reduction stage of high purity copper wires to produce $\mathrm{SO}_{2}, \mathrm{~N}_{2}, \mathrm{CO}_{2}$, and water. Water is removed using a Nafion ${ }^{\mathrm{TM}}$ membrane. Sulphur dioxide is resolved from $\mathrm{N}_{2}$ and $\mathrm{CO}_{2}$ on a packed $\mathrm{GC}$ column at a temperature of
$32{ }^{\circ} \mathrm{C}$. The resultant $\mathrm{SO}_{2}$ peak enters the ion source of the IRMS where upon it is ionized and accelerated. Gas species of different mass are separated in a magnetic field then simultaneously measured on a Faraday cup universal collector array. Analysis was based on monitoring of $m / z 48,49$ and 50 of $\mathrm{SO}^{+}$produced from $\mathrm{SO}_{2}$ in the ion source. Both references and samples are converted to $\mathrm{SO}_{2}$ and analysed using this method. The analysis proceeds in a batch process by which a reference is analysed followed by a number of samples and then another reference. The reference material used for sulphur isotope analysis of the pyrite samples was IA-R061 (barium sulfate, $\delta^{34} \mathrm{~S}_{\mathrm{V}-\mathrm{CDT}}=+20.33 \%$ ). IA-R061, IA-R025 (barium sulfate, $\delta{ }^{34} \mathrm{~S}_{\mathrm{V}-\mathrm{CDT}}=+8.53 \%$ ) and IA-R026 (silver sulphide, $\delta{ }^{34} \mathrm{~S}_{\mathrm{V}-\mathrm{CDT}}=+3.96 \%$ o) were used for calibration and correction of the ${ }^{18} \mathrm{O}$ contribution to the $\mathrm{SO}^{+}$ion beam. IAR061, IA-R025 and IA-R026 are in-house standards calibrated and traceable to NBS-127 (barium sulfate, $\delta{ }^{34} \mathrm{~S}_{\mathrm{CDT}}=+$ $20.3 \%$ ) and IAEA-S-1 (silver sulphide, $\delta{ }^{34} \mathrm{~S}_{\mathrm{V}-\mathrm{CDT}}=-0.3$ $\%$ ). NBS-127 and IAEA-S-1 are inter-laboratory comparison standards distributed by the International Atomic Energy Agency (IAEA) with internationally accepted $\delta{ }^{34} \mathrm{~S}$ values. For quality control purposes test samples of IA-R061 and IAEA-SO-5 (barium sulfate, $\delta{ }^{34} \mathrm{~S}_{\mathrm{V}-\mathrm{CDT}}=+0.50 \%$ ) were measured as quality control checks during batch analysis of the pyrite samples. IAEA-SO-5 is an inter-laboratory comparison standard distributed by the International Atomic Energy Agency (IAEA) with an internationally accepted $\delta{ }^{34} \mathrm{~S}$ value.

For geochronological investigations, zircons were extracted by conventional mineral separation using crushing, sieving, shaking table, heavy liquid and manual separation. Highestquality zircons were mounted in 1-inch epoxy resin discs, ground and polished to median sections and investigated by SEM-CL imaging to reveal internal chemical zonation features. The LA-ICP-MS analytical work was performed at the Laboratory of Geochronology, Centre for Earth Sciences, University of Vienna, Austria. Analytical procedures were identical to the methodology outlined in Klötzli et al. (2009). Zircon ${ }^{206} \mathrm{~Pb} /{ }^{238} \mathrm{U}$ and ${ }^{207} \mathrm{~Pb} /{ }^{206} \mathrm{~Pb}$ ratios and ages were determined using a $193 \mathrm{~nm}$ Ar-F excimer laser (NewWave UP193) coupled to a multi-collector ICP-MS (Nu Instruments II). Ablation using $\mathrm{He}$ as carrier gas was raster- wise according to the CL zonation pattern of the zircons. Line widths for rastering were $15 \mu \mathrm{m}$ with a rastering speed of $5 \mu \mathrm{m} / \mathrm{sec}$. Energy densities were $5-8 \mathrm{~J} / \mathrm{cm} 2$ with a repetition rate of $10 \mathrm{~Hz}$. The He carrier gas was mixed with the Ar carrier gas flow prior to the ICP plasma torch. Ablation duration was 60 to $120 \mathrm{~s}$ with a $30 \mathrm{~s}$ gas and $\mathrm{Hg}$ blank measurement preceding ablation. Ablation count rates were corrected accordingly offline. Remaining counts on mass 204 were interpreted as representing ${ }^{204} \mathrm{~Pb}$. Static mass spectrometer analysis was as follows: ${ }^{238} \mathrm{U}$ and ${ }^{232} \mathrm{Th}$ were measured in Faraday detectors, ${ }^{208} \mathrm{~Pb},{ }^{207} \mathrm{~Pb},{ }^{206} \mathrm{~Pb}$, and ${ }^{204}(\mathrm{~Pb}+\mathrm{Hg})$ in ion counter detectors, respectively. An integration time of $1 \mathrm{~s}$ was used for all 
measurements. The ion counter - Faraday and inter-ion counter gain factors were determined before the analytical session using reference zircon Plesovice (Sláma et al. 2008). Sensitivity for ${ }^{206} \mathrm{~Pb}$ on reference zircon Plesovice was c. $30^{\prime} 000 \mathrm{cps} / \mathrm{ppm} \mathrm{Pb}$. For ${ }^{238} \mathrm{U}$ the corresponding value was c. $35^{\prime} 000 \mathrm{cps} / \mathrm{ppm}$ U. Mass and elemental bias and mass spectrometer drift of both $\mathrm{U} / \mathrm{Pb}$ and $\mathrm{Pb} / \mathrm{Pb}$ ratios, respectively, were corrected applying the "intercept method" of (Sylvester and Ghaderi 1997). The calculated ${ }^{206} \mathrm{~Pb} /{ }^{238} \mathrm{U}$ and ${ }^{207} \mathrm{~Pb} /{ }^{206} \mathrm{~Pb}$ intercept values, respectively, were corrected for mass discrimination from analyses of reference zircon Plesovice measured during the analytical session using a standard bracketing method (Klötzli et al. 2007). The correction utilizes regression of standard measurements by a quadratic function. A common $\mathrm{Pb}$ correction was applied to the final data using the apparent ${ }^{207} \mathrm{~Pb} /{ }^{206} \mathrm{~Pb}$ age. Final age calculations were performed with Isoplot $\odot 3.0$ (Ludwig 2003). All errors reported for LA data are at the 2-sigma level. Reference zircon Plesovice (Sláma et al. 2008) was also used as secondary standard in order to test the overall reproducibility of the analytical method. 15 measurements made during the analytical session result in a concordia age of $338.8 \pm 2.6 \mathrm{Ma}$. This is within error identical to the accepted reference ${ }^{206} \mathrm{~Pb} /{ }^{238} \mathrm{U}$ date of $337.13 \pm 0.37 \mathrm{Ma}$ (Sláma et al. 2008).

\section{Results}

\section{Petrography, geochemistry and clay mineralogy}

As described, the rhyodacites have been grouped into Types I and II based on their colour. The bulk and trace element geochemistry of Type I (= AR 5) and Type II rhydacites (= AR 4) is listed in Table 1 (for comparison, it includes the geochemistry of rhyolitic dykes occurring $\mathrm{W}$ of the area under investigation, i.e. the "Josefsthal dyke" and "Lasenice dykes" respectively as given by Klećka and Vaňková 1988 and Breiter (1998). Sample AR 7 refers to a particular deep brown, coarse grained variety within Type I while AR 10 and AR 11 represent the most intensively altered varieties within Type II (see also Figs. 4 and 5). As shown in Fig. 6, the bulk composition plots into the rhyolite field, but in fact very closely to the trachydacite-dacite-rhyolite triple point. In spite of that, some parameters favour the rock to be named a "rhyodacite": (I) the low potassium feldspar content of $\sim 5 \mathrm{wt} \%$ vs a plagioclase (albite) content slightly above $30 \mathrm{wt} \%$ (see below); (ii) the hornblende (and biotite) content and (iii) the $\mathrm{SiO}_{2}$ content slightly below $70 \mathrm{wt} \%$. In spite of the significant different phenotypes, Type I and Type II display de facto the same chemistry with respect to the bulk composition. The only exception is the sulphur content which increases from $0,05 \%$ in Type I to $0,25 \%$ (max.: $0,6 \%$ ) in Type II which corresponds
LeBas et al 1986

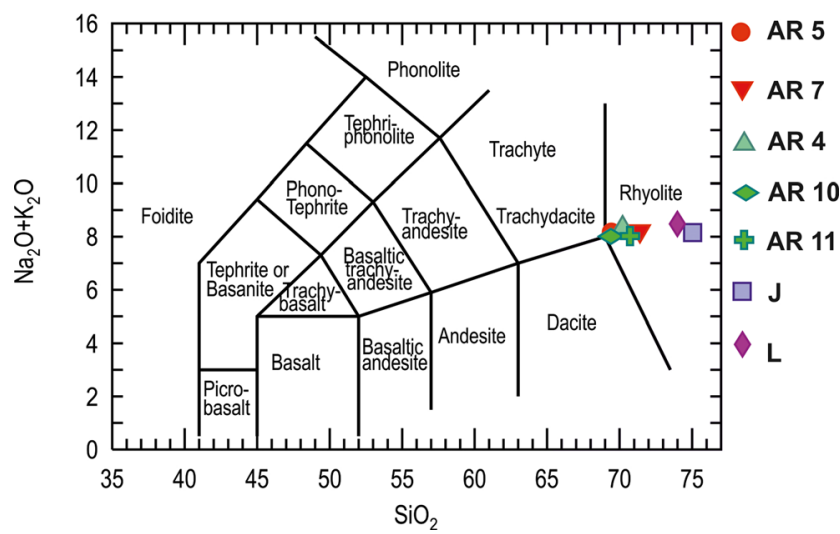

Fig. 6 TAS classification diagram of subvolcanic rocks (Le Bas et al. 1986; Le Maitre 2002) from the quarry Arnolz and of felsitic dykes from Josefsthal (Breiter 1998) and Lásenice (Klećka and Vaňková 1988); the plot clearly emphasizes the geochemical difference between the Arnolz samples and the felsitic dykes further to the NW

well to the presence of pyrite in the latter. In other words, the alteration as characterized in particular by the formation of pyrite was not associated with any significant enrichment or depletion of major or trace elements respectively. Moderate differences in iron, magnesium and calcium contents in samples AR 7, AR 10 and AR 11 (compared to AR 5 and AR 4 samples) are interpreted as a result of local alteration. It has to be emphasized, that AR 10 and AR 11 display the highest sulphur contents of $0.5 \%$ and $0.6 \%$, respectively, indicating the obvious correlation of progressing alteration and pyrite mineralization. In accordance with the bulk chemistry, trace element concentrations mirror the geochemical similarity of Type I and Type II lithologies. The $\mathrm{K} / \mathrm{Rb}$ ratio around 300 (AR 5 and AR 4) corresponds fairly well with the crustal average (Wedepohl 1995). Slightly increased $\mathrm{F}$ and $\mathrm{Rb}$ concentrations in Type II rocks compared to Type I might reflect the alteration of Type II. Again, the concentration of none of the elements likely to be increased during geochemical specialization exceeds the relevant crustal averages. This lack of any geochemical specialization is also emphasized by a $\mathrm{Th} / \mathrm{U}$ ratio of $>1$. The concentrations of all base and precious metals analysed are close to or even below the relevant detection limits. Trace element contents are in accordance with the unspecialised bulk geochemistry: fairly low contents of $\mathrm{Ba}$ and $\mathrm{Sr}$, low contents of $\mathrm{F}$ and $\mathrm{Rb}$, giving rise to a $\mathrm{K} / \mathrm{Rb}$ ratio of 182 and a $\mathrm{Rb} / \mathrm{Sr}$ ratio of 2.7. These figures, together with the $\mathrm{Th} / \mathrm{U}$ ratio of $>1$, emphasize the lack of any kind of geochemical differentiation and specialization. A single, elevated $\mathrm{W}$ content of $19 \mathrm{ppm}$ remains unexplained. The $\mathrm{S}$ content of $0.2 \%$ reflects the pyrite content close to the contact.

The mineralogical investigation of the heavy mineral concentrate revealed the following accessory minerals: needle shaped apatite is the most frequent accessory mineral followed by zircon, epidote, titanite, anatas and rutile. 
XRD investigations (Fig. 7) indicate that chlorite, sericite, smectite and kaolinite are the clay minerals within the matrix. Chlorite content varies between 5 and $20 \mathrm{wt} \%$, sericite content between 5 and $20 \mathrm{wt} \%$ and kaolinite and smectite contents between $<5$ and $10 \mathrm{wt} \%$. However, the clay minerals are distributed irregularly amongst the samples investigated and do not show a systematic distribution between Type I and Type II nor was it possible to decipher a time-related sequence of their formation. Potassium feldspar, not recognized microscopically, is present in the matrix by XRD (orthoclase) and amounts to around 5 to $10 \mathrm{wt} \%$ in all volcanic rocks disregarding their phenotypes; its average grain size is well below $100 \mu \mathrm{m}$ and its geochemistry, analysed via electron

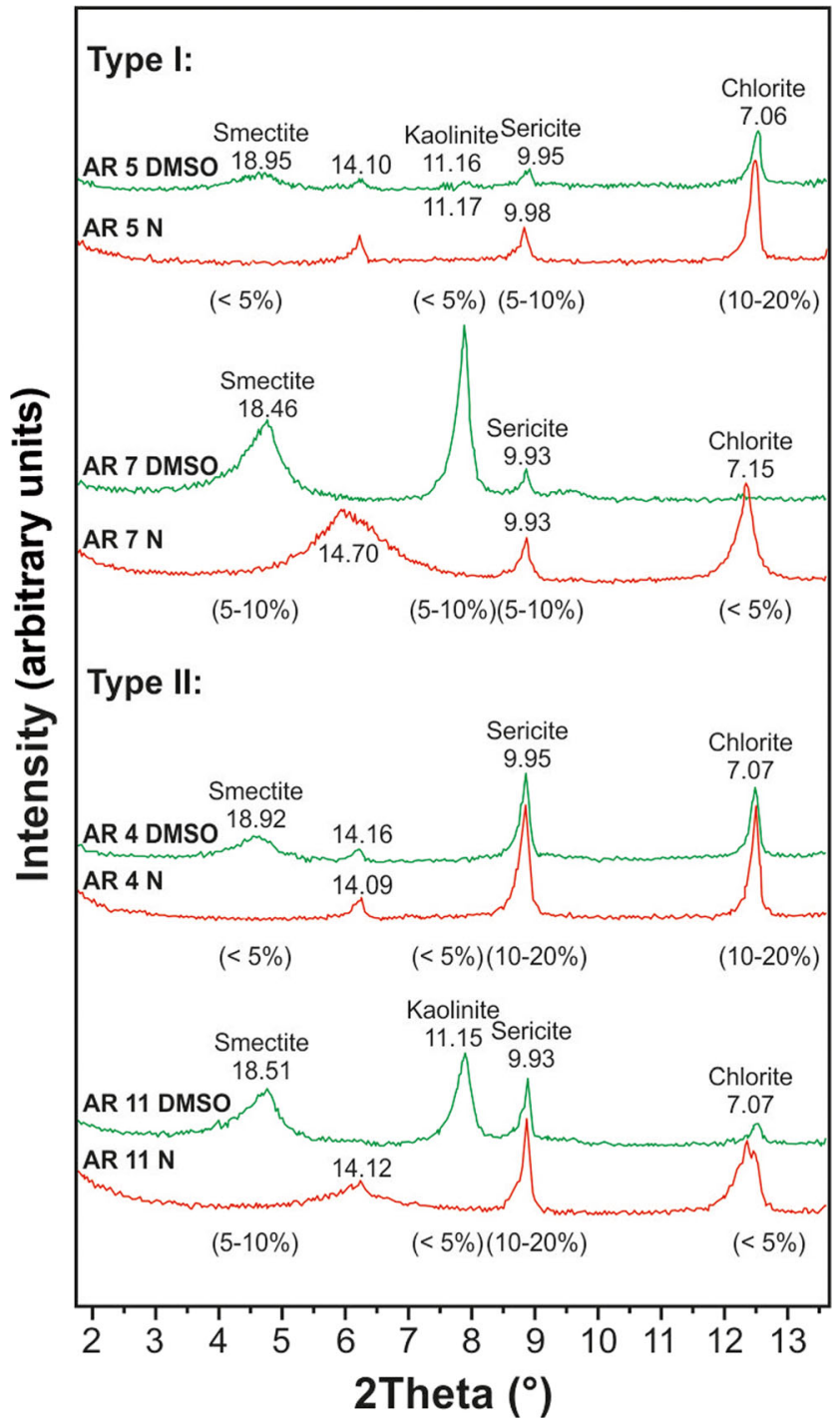

Fig. 7 X-ray diffraction patterns of Type I (AR5, AR7) and Type II (AR, AR11) rhyolites, air-dried (N) and after DMSO (dimethyl sulfoxide) treatment (after Moore and Reynolds 1997). Confirmation is accomplished by DMSO intercalation and expansion of interlayers. Quantitative estimates of clay minerals (chlorite, sericite, kaolinite, smectite) are based upon Schultz 1964. The amounts (vol\%) refer to the total samples; d-values of clay minerals in $\AA$ microprobe, matches the composition of an almost pure $\mathrm{K}$ feldspar containing $\approx 0.5 \mathrm{wt} \%$ sodium (6 grains, 14 single analyses). Matrix-bound plagioclase - approximately $30 \mathrm{wt} \%$ - corresponds to an almost pure albite with $\approx 1.5 \mathrm{wt} \% \mathrm{CaO}$ ( 5 grains, 22 single analyses). The plagioclase phenocrysts could not be analysed due to their pervasive sericitization.

Sulphur isotope data are listed in Table 2. The $\delta{ }^{34} \mathrm{~S}$ values data of rhyodacites and granite hosted pyrites overlap fairly well, ranging from +0.07 to $-2.22 \%$.

Two samples have been prepared for geochronological analyses. One sample is from the granite locally corresponding to sample AR 2 (Fig. 3, sample AR1-4 in Table 3) and one sample was taken from Type II rhyodacite (sample SM4-5, Fig. 3, Table 3).

\section{U-Pb zircon dating}

Zircons from the granite sample AR1-4 show typical igneous features. They are short- to medium prismatic and all exhibit igneous oscillatory zoning. Some crystals contain inherited cores. Alteration due to reaction with metasomatic fluids along the rims and in some metamict core regions is common. Twelve crystals with a total of 19 lines have been analysed, the data are presented in Table 3 and Fig. 8. In the analysed crystals there is no obvious correlation between apparent age, zonation and/or position within the crystal. 12 data points form a slightly discordant cluster around 320-300 Ma. Calculating a fixed discordia with the upper-intercept at ${ }^{207} \mathrm{~Pb} /{ }^{206} \mathrm{~Pb}=0.85 \pm 0.05$, representing modern lead, results in a lower-intercept age of $312 \pm 4 \mathrm{Ma}$. A second nearconcordant cluster of 4 data points results, using the same procedure, in a lower-intercept of $504 \pm 4 \mathrm{Ma}$. The remaining 3 data points are situated highly discordantly between these two clusters. The lower intercept age of $313 \pm 4$ Ma derived for the purely igneous zircons is interpreted as dating zircon growth during the cooling of the granite AR1-4 melt during or shortly after emplacement. The older age at $504 \pm 4 \mathrm{Ma}$ is interpreted as representing a major contribution of a possibly igneous inheritance. The nature of such a protolith is not clear inasmuch as such a Cambrian age is not found elsewhere in the region of Arnolz in this part of the Moldanubian zone.

Table 2 Sulphur isotope composition of pyrites in granite and rhyodacites. In spite of minor variance, both data sets overlap

\begin{tabular}{|c|c|c|c|c|c|c|}
\hline & \multicolumn{3}{|c|}{ Granite hosted pyrite } & \multicolumn{3}{|c|}{ Rhyodacite hosted pyrite } \\
\hline & GR & Py 5 & Py 6 & Py 1 & Py 2 & Py 3 \\
\hline \multirow[t]{2}{*}{$\delta^{34} \mathrm{~S}$} & $-0,48$ & 0,08 & $-1,46$ & $-1,59$ & $-2,16$ & $-0,67$ \\
\hline & $-0,65$ & 0,05 & $-1,50$ & $-1,42$ & $-2,28$ & $-0,48$ \\
\hline Average & 0,57 & 0,07 & $-1,48$ & $-1,51$ & $-2,22$ & $-0,58$ \\
\hline
\end{tabular}




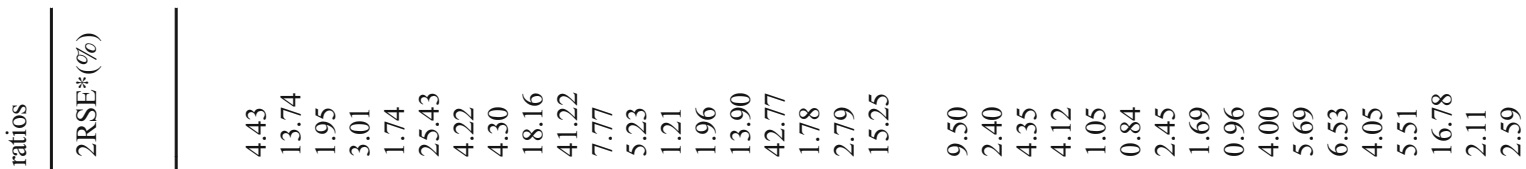

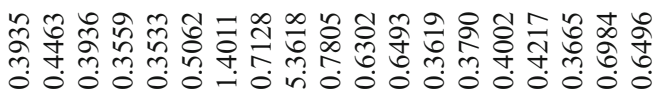

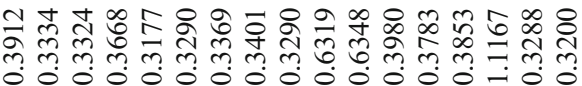

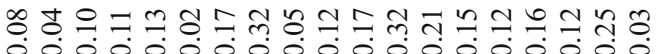

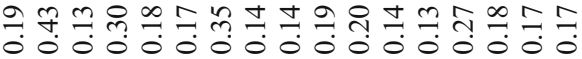

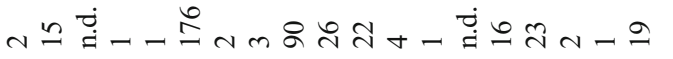

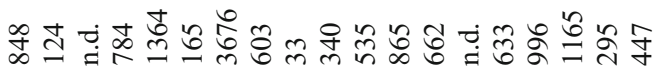

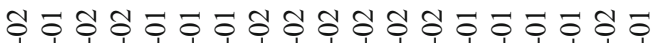

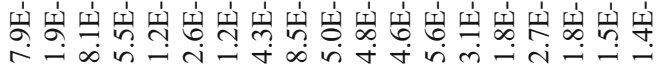

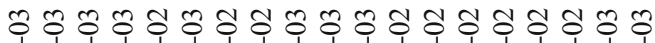

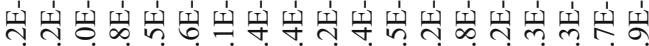
तु

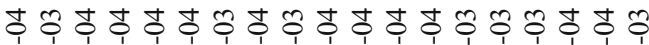

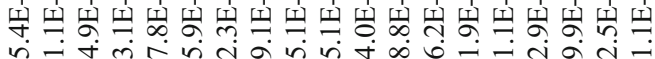

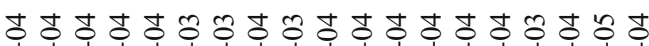

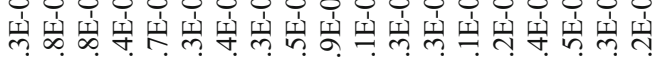

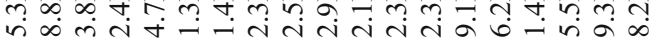

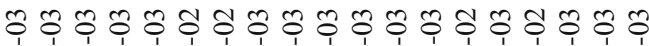

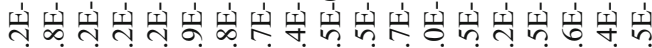

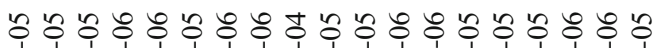

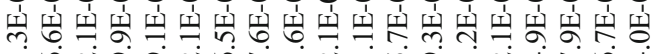
m.

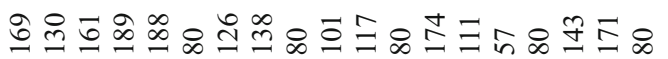

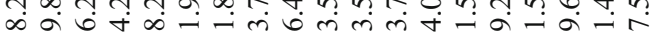

ت্்

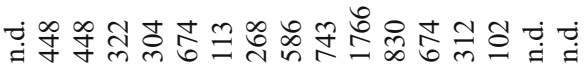

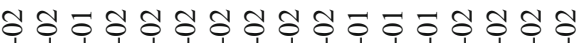

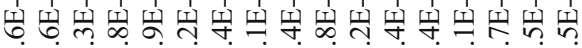

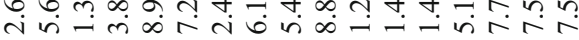

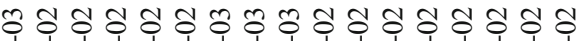

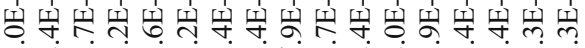
n

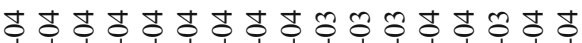

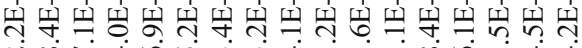

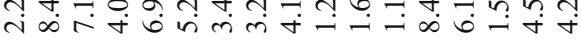

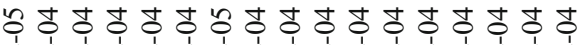

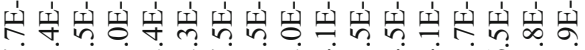

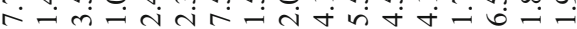

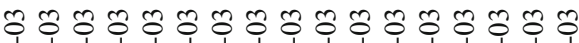

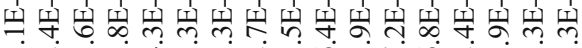

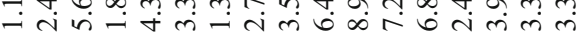

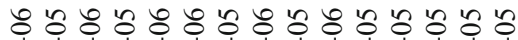

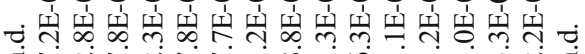
$=$ तरतก

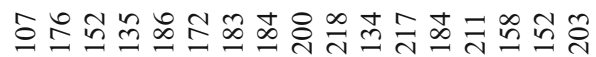

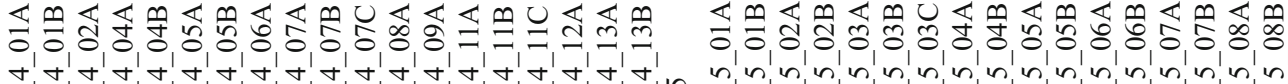

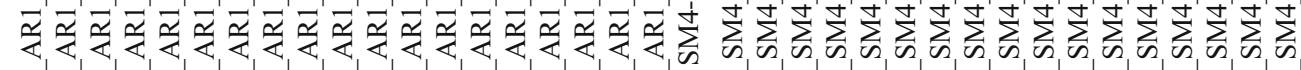
$\approx 00000$

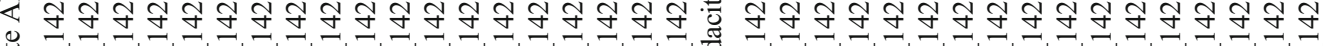

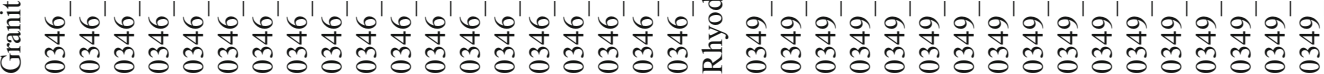




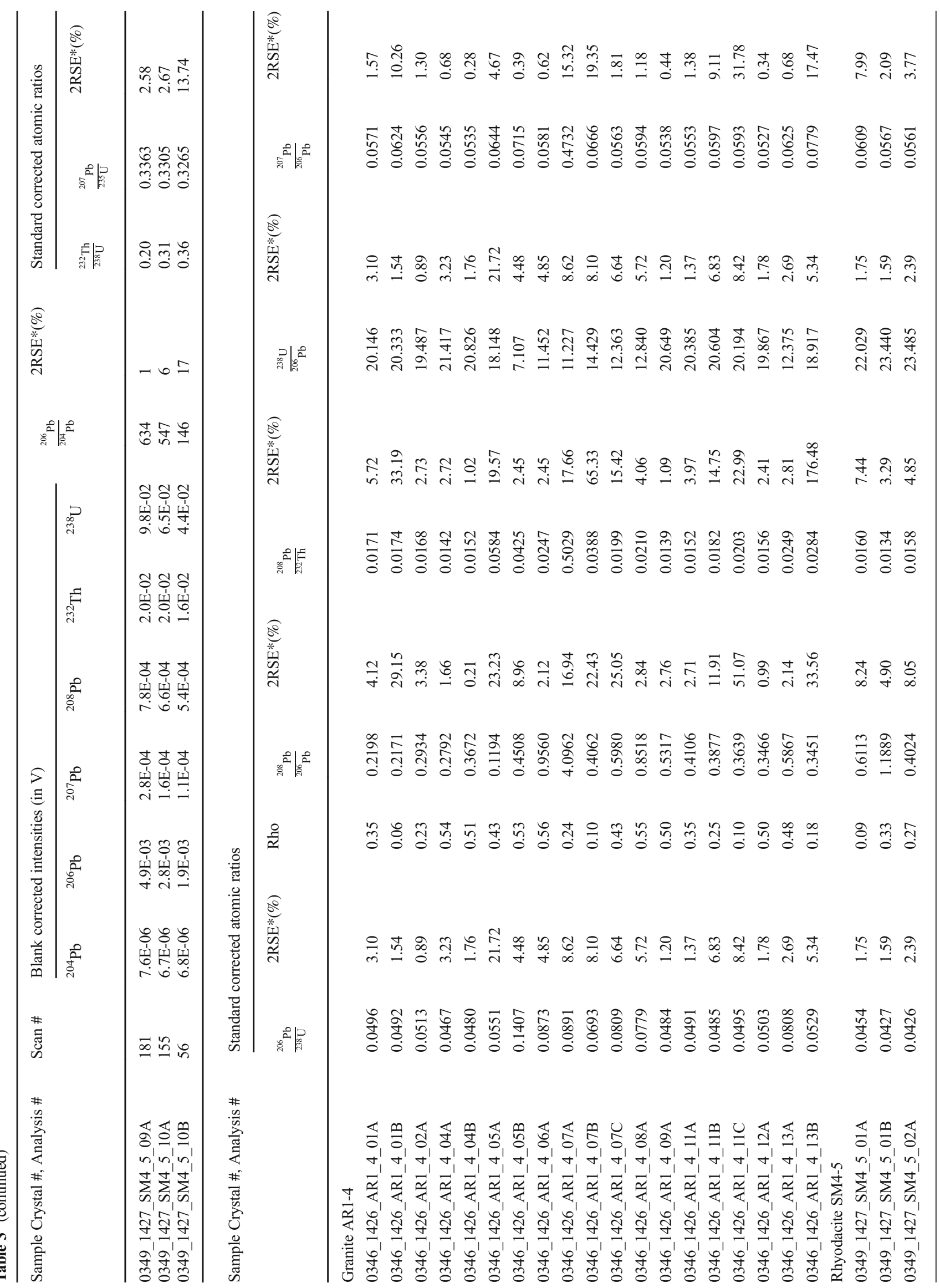




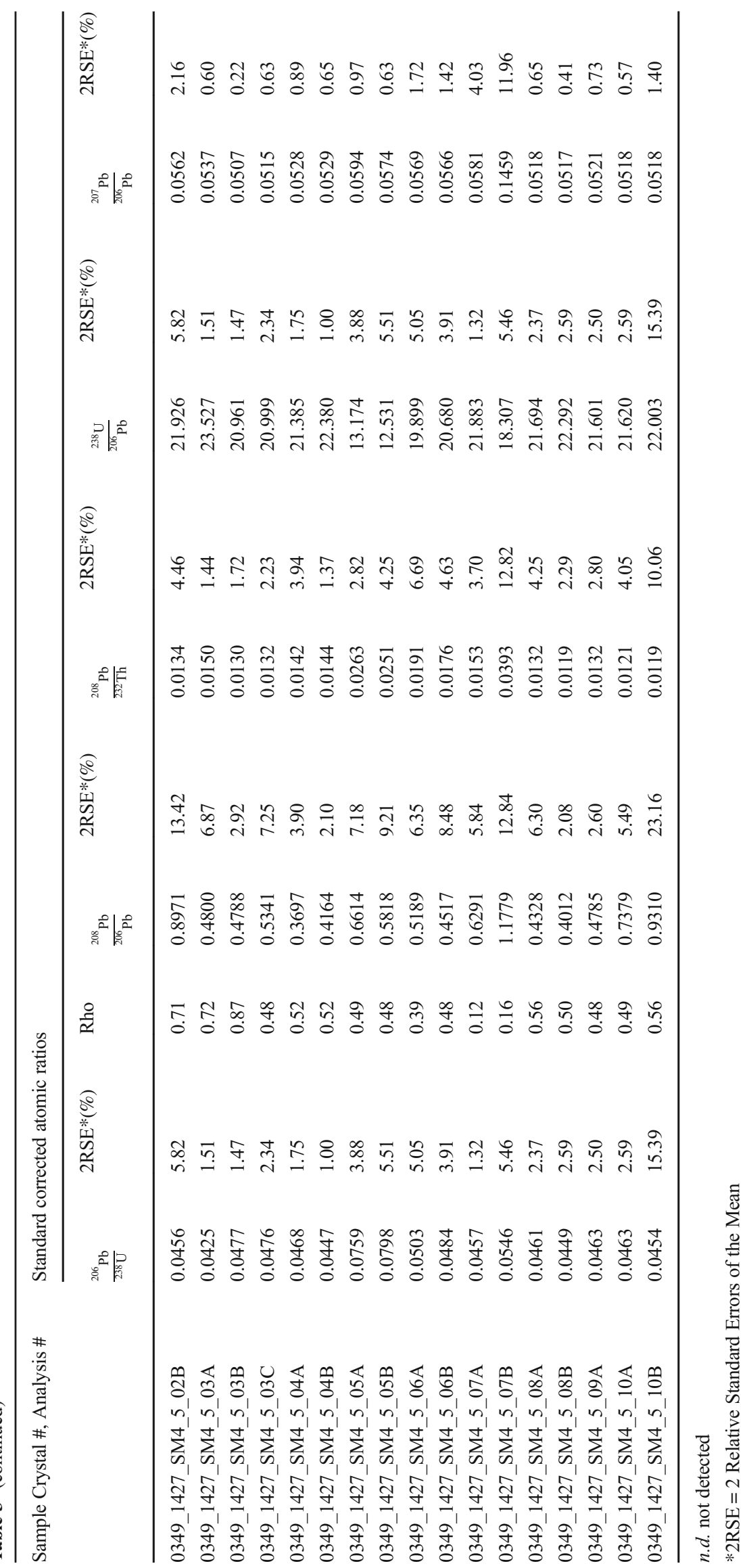




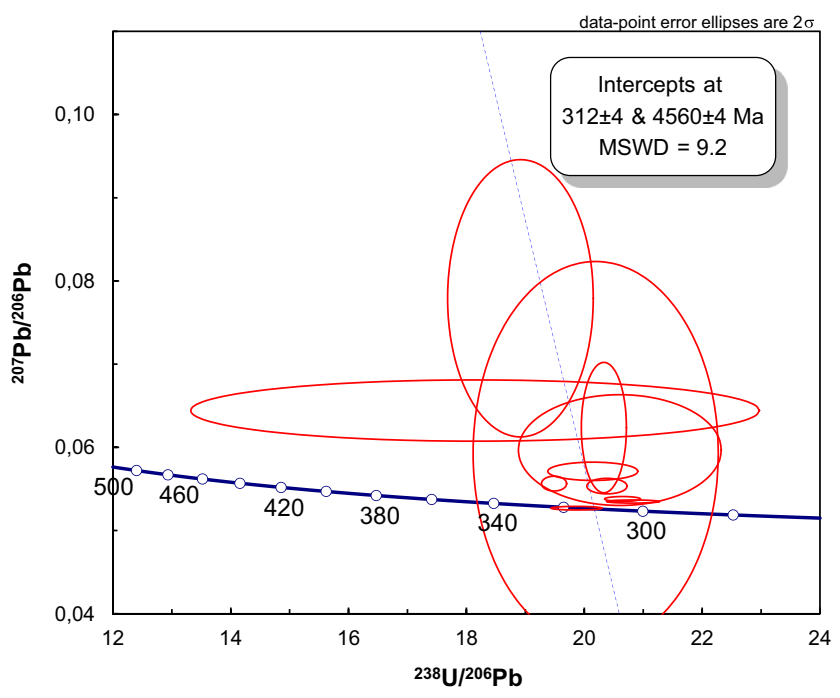

Fig. 8 Tera-Wasserburg concordia plot of the U-Pb data derived from the igneous zircons from granite sample AR1-3 (mount 0346-1426). The discordia is calculated using a fixed upper-intercept point representing modern lead with an estimated "age" of c. $4.5 \mathrm{Ga}$. The lower-intercept $\mathrm{U}-\mathrm{Pb}$ age of $312 \pm 4 \mathrm{Ma}$ is interpreted as representing the minimum age of emplacement of the biotite-granite

Zircons from the rhyodacite SM4-5 can be grouped into two different populations. Population 1 comprises typical long prismatic (elongation > 8:1, Fig. 9) crystals with a well developed internal oscillatory zonation with only a few inclusions and no alteration. Some crystals show a typical glassy growth spindle parallel the c-axis. These population 1 zircons are interpreted as forming the rhyodacitic melt zircons proper. Zircons from the second population are more varied in their appearance (elongation < 5:1 Fig. 10). They are short- to medium-prismatic and often exhibit igneous oscillatory zoning. Some crystals contain inherited cores. Practically all crystal surfaces are strongly to extremely etched. Etching surfaces discordantly disrupt the internal oscillatory zonation thus clearly demonstrating that etching is younger than crystal growth. Alteration due to reaction with fluids along the rims and in some metamict core regions is also common. We dated a total of 11 crystals with a total of 21 lines. The analytical data are presented in Table 3 and Fig. 11. In the granite sample AR1-3 analysed crystals show no obvious correlation between apparent age, zonation and/or position within the crystal. 13 data points form a slightly discordant cluster around 300 $285 \mathrm{Ma}$. Calculating a fixed discordia with all analyses and the upper-intercept at ${ }^{207} \mathrm{~Pb} /{ }^{206} \mathrm{~Pb}=0.85 \pm 0.05$, representing modern lead, results in a lower-intercept age of $289 \pm 4 \mathrm{Ma}$. Calculating a fixed discordia with the 6 most concordant analyses and the upper-intercept also at ${ }^{207} \mathrm{~Pb} /{ }^{206} \mathrm{~Pb}=0.85 \pm 0.05$ results in a lower-intercept age of $292 \pm 4 \mathrm{Ma}$. This is within error identical to the former lower intercept age. Five of the remaining 7 analyses are also straddling the discordia, two data points are far off. Two analyses define a concordia age of $478 \pm 4 \mathrm{Ma}$. The remaining 5 analyses are strongly discordant. The more closely defined lower intercept age of $292 \pm$ $4 \mathrm{Ma}$ is interpreted as the age of emplacement of the rhyodacitic melt. The rhyolite SM4-5 is thus ca. 20 Ma younger than the host granite AR1-4. This is in complete agreement with field evidence (Fig. 3). The inheritance dated at $478 \pm$ 4 Ma shows that the rhyodacitic melt is in parts derived from the "classical" Ordovician basement which is well known throughout the Moldanubian zone of the Bohemian Massif. Interestingly the cluster of inherited ages around $504 \pm 4 \mathrm{Ma}$ from granite sample AR1-3 and the cluster of inherited ages at $478 \pm 4$ Ma from rhyodacitic sample SM4-5 are not identical. This might indicate that the melts forming the two different rocks were not derived from exactly the same protolith.

\section{Discussion}

Subvolcanic dykes of dioritic, dacitic and rhyolitic composition within and at the periphery of the Austrian part of the South Bohemian Pluton have been described by several authors (Waldmann 1950; Zwicker 1953; Scharbert 1957;
Fig. 9 Secondary electron (SE) and cathodoluminescens (CL) images of long-prismatic zircon crystals from sample SM4-5 (mount 0350-1427) exhibiting a typical internal igneous oscillatory zonation. These crystals are interpreted as representing crystals grown in the rapidly cooling rhyodacitic melt during emplacement of the dykes
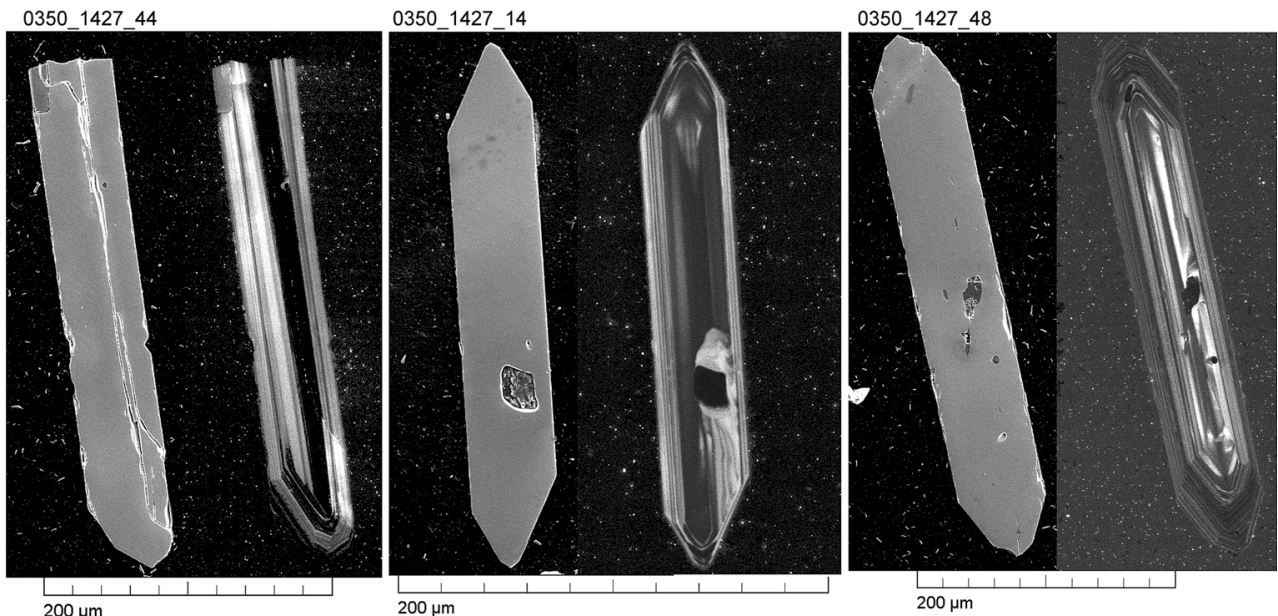
Fig. 10 SE and CL images of short-prismatic to stubby zircon crystals from sample SM4-5 (mount 0350-1427) exhibiting a variety of typical internal igneous oscillatory zonation patterns and dissolution pits and surfaces. The latter two are characteristic for inherited xenocrysts having been entrained in the $\mathrm{Zr}$-undersaturated melt during the early stages of the formation of the rhyodacites

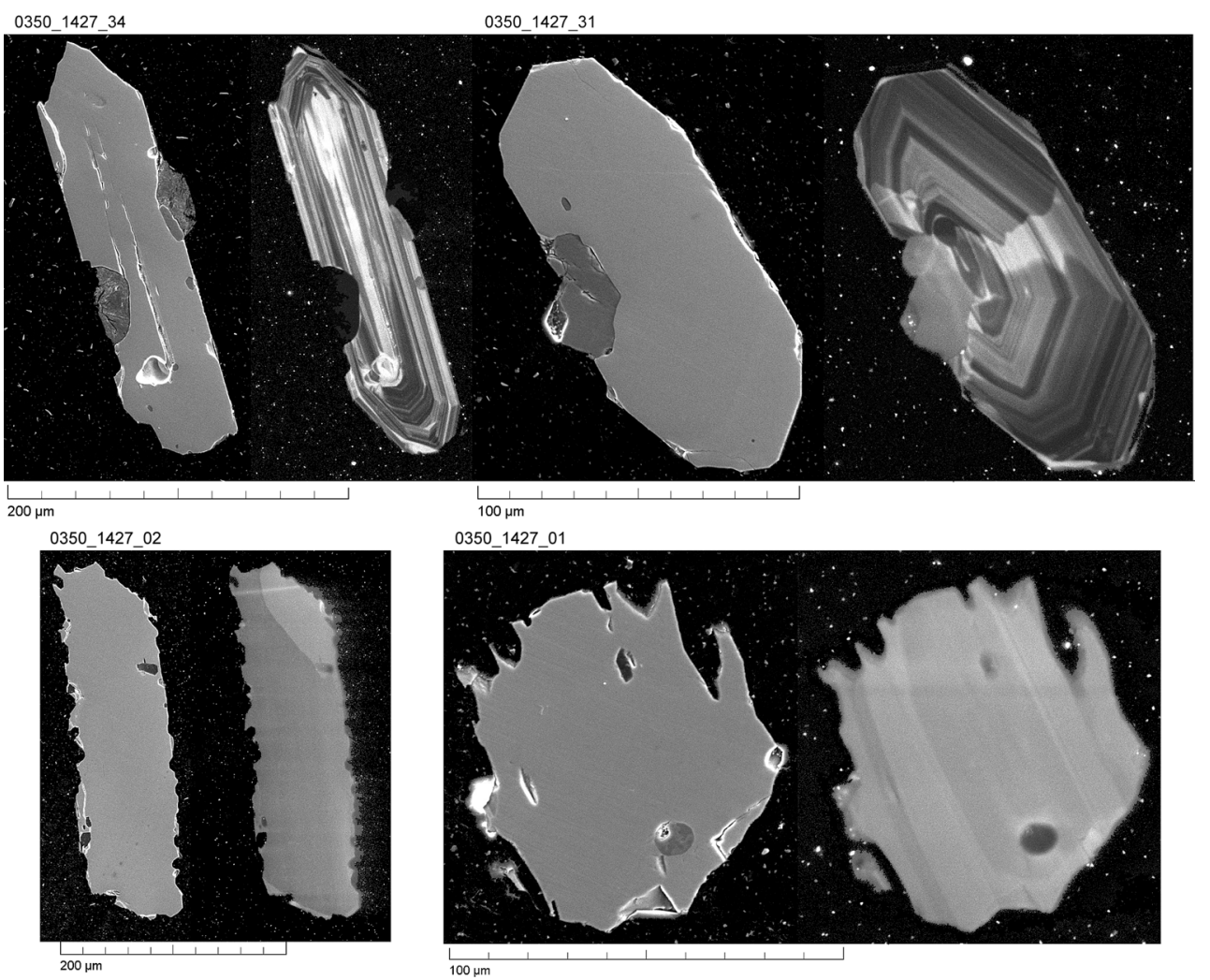

Breiter 1998; Klomínský et al. 2010a, 2010b), while comparable dykes from the south-western periphery of the Moldanubian zone in Bavaria have been reported by Dill (1991). As shown in Fig. 1, subvolcanic, "felsitic" dykes

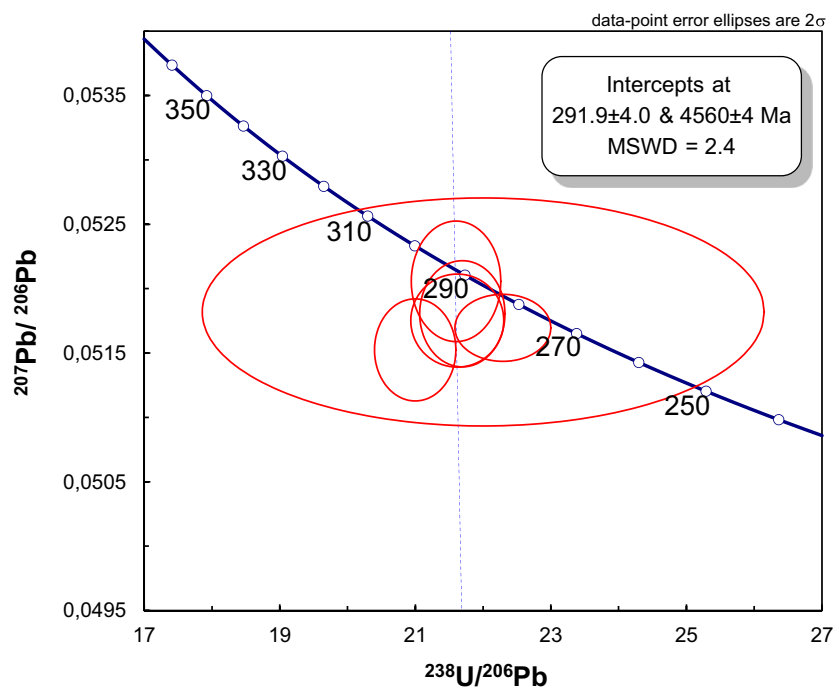

Fig. 11 Tera-Wasserburg concordia plot of the U-Pb data derived from the long-prismatic igneous zircons from rhyodacitic sample SM4-5 (mount 0349-1427). The discordia is calculated using a fixed upperintercept point representing modern lead with an estimated "age" of c. $4.5 \mathrm{Ga}$. The lower-intercept U-Pb age of $292 \pm 4 \mathrm{Ma}$ is interpreted as representing the time of emplacement of the rhyodacite into the finegrained biotite-granite host-rock with an age of $312 \pm 4 \mathrm{Ma}$ (see above) occur regionally $\mathrm{W}, \mathrm{NW}$ and $\mathrm{N}$ of the area investigated at present. These "felsitic dykes" (i.e. "Litschau dyke swarm" sensu Klomínský et al. 2010b) include rhyolites, granite porphyries and dyke-like, fine grained leucocratic granites respectively (Klećka and Vaňková 1988; Breiter and Scharbert 1995; Breiter; 1998). They have been described as subvertical, up to some $\mathrm{km}$ in length with thicknesses varying between 2 to $20 \mathrm{~m}$. According to these authors, they are also part of a longer "zone of volcano-tectonic activity" striking approximately NW to $\mathrm{N}$ from the area around Litschau (Austria) to Lásenice (Czech Republic) for about 20 km (Fig. 1). Similar felsitic dykes, locally wolframite bearing (Klećka 1986, 1992), are known even farther to the $\mathrm{N}$ of Lásenice around the township of Pelhrimov (Vrána 1990; not shown in Fig. 1). Equally, NW of Litschau, a highly fractionated albite - Limuscovite-topaz granite, referred to as "Homolka granite", occurs within this regional zone. This granite and the felsitic dykes related to it are geochemically specialized (Breiter and Scharbert 1995; Fig. 1, Table 1). The Homolka granite yields a $\mathrm{Rb} / \mathrm{Sr}$ whole rock age of $319 \pm 7 \mathrm{Ma}$ (Breiter and Scharbert 1995) whereas the felsitic dykes (around Lásenice) yield a Rb/ Sr whole rock age of $295 \pm 5$ Ma (Klećka et al. 1994) emphasizing the dykes to be younger by approximately $20 \mathrm{Ma}$. De facto identical ages have been determined for the rhyodacites and their hosting granite in the quarry of Arnolz: an U/Pb age of of $312 \pm 4 \mathrm{Ma}$ for the granite vs an age of $292 \pm 4 \mathrm{Ma}$ for the rhyodacites equally emphasizing a time gap between the 
granite and the rhyodacitic intrusion of ca. 20 Ma. In this context, it is worthwhile to mention, that the very same time gap between granite formation and the intrusion of associated rhyolite dykes has been reported from a granite in the Erzgebirge ("Eibenstock granite"), Germany (Kempe et al. 2004).

Though these ages correspond perfectly - not to say, they are identical - the rhyodacitic dyke from quarry Arnolz differs from the Litschau - Homolka - Lasenice dykes significantly in several aspects.

(1) Spatial orientation: whereas the Litschau-HomolkaLasenics dykes in the NW strike ca. $340^{\circ}$ (Fig. 1) the dyke in quarry Arnolz strikes NNE-SSW with $10^{\circ}-15^{\circ}$. That significant shift in the strike direction coincides roughly with the lithological contact of the South Bohemian Pluton to the paragneisses of the Monotonous Series. The regional importance of this structure, separating two different tectonic regimes, has recently been stressed by Žak et al. (2011).

(2) Geochemistry: as described, bulk and trace element compositions of the rhyodacites studied are "unspecialised", lacking any enrichment of elements indicative for minerogenetic processes (Table 1). In sharp contrast, the analyses of the dykes to the NW around Josefsthal and Lasenice match the chemistry of fractionated granites, enriched, e.g., in $\mathrm{Rb}, \mathrm{Li}, \mathrm{Cs}, \mathrm{F}, \mathrm{P}$ and $\mathrm{U}$ pointing to their geochemical consanguinity with the Homolka granite (Tab 1). Therefore a different magmatic source for the rhyodacites at Arnolz compared to the dyke system to the NW, including the Homolka granite, is assumed.

(3) Alteration phenomena: the rhyodacites in quarry Arnolz have been affected by two hydrothermal events. The older one, assumed to be contemporaneous with the intrusion of the rhyodacitic magma itself and caused by an oxidising fluid, gave rise to a pervasive oxidation, causing the reddish to brownish colour characterizing the Type I rhyodacite. A second hydrothermal fluid with reducing chemistry overprinted that alteration causing the greenish colour of Type II rhyodacites. The relative age relationship of these two hydrothermal events is clearly seen in the quarry. However, it might well be, that these two hydrothermal events grade into each other and represent more or less contemporaneous events. The hydrothermal alterations gave rise to the formation of chlorite, sericite, kaolinite and smectite, the latter predominantly derived from previously existing volcanic glasses. This paragenesis is in accordance with an epithermal fluid of weakly acidic to neutral $\mathrm{pH}$ and temperatures around $200^{\circ} \mathrm{C}$ (Thompson and Thompson 1996; Pirajno 2009). No explanation for the change from an oxidising hydrothermal fluid to a reducing one can be given. The fluids were barren with respect to base elements, molybdenum and precious elements, but were enriched in $\mathrm{S}$ giving rise to the formation of the disseminated pyrite mineralization which is exclusively associated with the second, reducing fluid. Such alteration phenomena have been so far unknown in the Southern Bohemian Massif. Neither the Homolka granite nor the dykes related to it display any signs of such hydrothermal alterations and sulphide mineralizations. Pyrite is the only sulphide observed so far. Based on field observations, the pyrite mineralization extends along strike for at least $3 \mathrm{~km}$ but an additional extension of another $4 \mathrm{~km}$ is not unlikely to occur which suggests a possible extension of the mineralization up to $7 \mathrm{~km}$.

S-isotope investigations: generally spoken the isotopic composition of sulphur in mantle rocks is similar to that of meteorites (Faure and Mensing 2005). Therefore, a deviating isotope value of a particular sample points to processes which have affected the original composition since their introduction into the crust (Faure and Mensing 2005). The $\delta{ }^{34} \mathrm{~S}$-values of basalts and gabbros respectively are reported as $+1.0 \pm 3.2 \%$ o (Seal 2006). Granitoids display an average $\delta{ }^{34} \mathrm{~S}$-value of $+1.0 \pm 6.1 \%$, ranging from -11 to $+14.5 \%$ (Seal, ibidem) whereas a slightly different $\delta^{34} \mathrm{~S}$ spread for granites of -4 to $+9 \%$ is given by Hoefs (2009). The wider spread of $\delta{ }^{34} \mathrm{~S}$ values in case of granites is explained by assimilation or partial melting of sedimentary rocks (Seal 2006). Positive $\delta{ }^{34} \mathrm{~S}$ values are said to occur due to the incorporation of sulfate bearing marine sediments and negative values by melting of sedimentary or metamorphic rocks enriched in ${ }^{32} \mathrm{~S}$ (by bacterial fractionation; Faure and Mensing 2005). The sulphur isotope composition of the rhyodacites in the quarry Arnolz varying between +0.07 and $-2.22 \%$ favours a magmatic origin of the sulphur in the given system while the slight negative values might point to some minor sedimentary contamination.

Extended disseminated sulphide mineralizations associated with hydrothermally altered (sub-) volcanic lithologies remind to alteration phenomena related to porphyry (copper) style mineralizations. The paragenesis chlorite-sericite-smectitepyrite in the quarry Arnolz corresponds phenomenologically to what is referred to as sericitic (phyllic) alteration zone and/or propylitic zone known from peripheral parts of porphyry systems (Thompson and Thompson 1996; Seedorf et al. 2005; Sillitoe 2010). The alteration in quarry Arnolz therefore phenomenologically resembles distal parts of a porphyry system.

However, in spite of these similarities, the lithology in quarry Arnolz differs significantly from classic porphyries as it lacks (i) quartz veinlets or quartz veinlet stockworks, (ii) even traces of sulphides other than pyrite and (iii) minerals frequently associated with sulphide minerals in porphyries like, i.a., anhydrite or tourmaline (Sillitoe 2010). There are 
also no observations pointing to multiphase magmatic events and related hydrothermal activities respectively as described from classic porphyry deposits (e.g. Spencer et al. 2015) and, finally, there are no signs of hydrothermal breccias frequently occurring in apical parts of porphyries (Sillitoe 2010).

\section{Conclusions}

- Subvolcanic rhyodacitic dykes dated at $295 \mathrm{Ma}$ - intruded various granites of the South Bohemian Pluton and surrounding Precambrian paragneisses in the Early Permian.

- Two different dyke systems occur in close spatial vicinity: the felsitic dykes around Litschau-Homolka-Lasenice ("Litschau dyke swarm"; Klomínský et al. 2010b), predominantly striking NW to $\mathrm{N}$ are geochemically specialized in the sense that they derived from highly differentiated granitic magmas (c.f., Homolka granite!) in contrast to the studied dykes in and around the quarry Arnolz. The latter strike NNE and differ by their non-specialized geochemistry, by their alteration phenomena and by an associated disseminated pyrite mineralization. This pyrite mineralization extending for a minimum of $3 \mathrm{~km}$ along strike was so far unknown in the South Bohemian Massif.

- Based on these observations and data, a separate magmatic source for the rhyodacites at Arnolz is assumed. The differences in the geochemical composition coincides with a shift in dyke orientation from NW-SE to NNESSW indicating two different tectonic regimes.

- Further investigations should primarily focus on a geophysical survey tracing the rhyodacites and their disseminated pyrite mineralisation along strike with emphasis on locating the possible parental magma chamber.

\footnotetext{
Acknowledgments Open access funding provided by University of Vienna. We would like to thank Andrea Mundl, Faculty of Earth Sciences, Geography and Astronomy, Center of Earth Sciences, University of Vienna for microprobe analyses of feldspars. We thank Lutz Nasdala, Institute for Mineralogy and Crystallography, Faculty of Earth Sciences, Geography and Astronomy for identification of heavy minerals via Raman spectroscopy and we thank Theo Ntaflos, Faculty of Earth Sciences, Geography and Astronomy for general support and fruitful discussions. We also thank Wolfgang Zirbs, Institute of Mineralogy and Crystallography for preparing various plots and last but not least Christoph Iglseder, Geological Survey of Austria, for compiling Fig. 1. We also thank two reviewers for their effort and critical comments and also the handling editor.
}

Open Access This article is distributed under the terms of the Creative Commons Attribution 4.0 International License (http:// creativecommons.org/licenses/by/4.0/), which permits unrestricted use, distribution, and reproduction in any medium, provided you give appropriate credit to the original author(s) and the source, provide a link to the Creative Commons license, and indicate if changes were made.

\section{References}

Breiter K (1998) Genetic significance of phosphorus in fractionated granites; International Geological Correlation Programme, Project 373Correlation, Anatomy and Magmatic-Hydrothermal Evolution of OreBearing Igneous Systems, International Conference, Czech Republic, Peršlák, Excursion Guide, Czech Geol. Survey, Prague

Breiter K (2010) Geochemical classification of Variscan granitoids in the Moldanubicum (Czech Republic, Austria). Abh Geol B A 65:19-25

Breiter K, Scharbert S (1995) The Homolka centre-an example of late Variscan ore bearing magmatism in the South Bohemian Batholith (Southern Bohemia, Northern Austria). J Geol B 138:9-25, Vienna

Breiter K, Scharbert S (1996) The Eisgarn granite and its successors in the South Bohemian Batholith. Mitt Öst Min Ges 141:75-76

Dill H (1991) Volcanic and volcanoclastic rocks at the Southwestern edge of the Bohemian Massif. Z Geol Wiss 19:519-537

Faure G, Mensing TM (2005) Isotopes - principles and applications, 3rd edn. Wiley, Hoboken

Finger F, Gerdes A, Janoušek V, René M, Riegler G (2007) Resolving the Variscan evolution of the Moldanubian sector of the Bohemian Massif: the significance of the Bavarian and the MoravoMoldanubian tectonomorphic phases. J Geosci 52:9-28

Friedl G (1997) U-Pb Datierungen an Zirkonen und Monaziten aus Gesteinen vom österreichischen Anteil der Böhmischen Masse. Dissertation University of Salzburg

Geological map of the Czech Republic 1:50 000, sheet 33-11 Trebon (1988), sheet 33-12 Nova Bystrice (1990), sheet 23-33 Veseli Nad Luznici (1990), sheet 23-34 Jindrichuv Hradec (1991)

Gerdes A, Friedl G, Parrish RR, Finger F (2003) High-resolution geochronology of Variscan granite emplacement - the South Bohemian Batholith. J Czech Geol Soc 48:53-54

Göd R, Kurzweil H, Klötzli U (2015) First report on the occurrence of subvolcanic rhyodacites and their associated alteration phenomenaBohemian Massif, Austria. Mitt Österr Min Ges 161:37

Hoefs J (2009) Stable isotope geochemistry, 6th edn. Springer, Berlin Heidelberg

Kempe U, Bombach K, Matukov D, Schlothauer T, Sergeev S (2004) Pb/ $\mathrm{Pb}$ and $\mathrm{U} / \mathrm{Pb}$ zircon dating of subvolcanic rhyolite as a time marker for Hercynian granite magmatism and $\mathrm{Sn}$ mineralisation in the Eibenstock granite, Erzgebirge, Germany: considering effects of zircon alteration. Mineral Deposita 39:646-669

Klećka M (1986) New found of tungsten mineralization in the Jindrichuv Hradec area. Čas Mineral Geol 31:314-315, in Czech

Klećka M (1992) Lásenice near Jindrichuv Hradec (Vojírov gamekeeper's lodge), a subvolcanic felsic dike with tungsten mineralization; Lepidolite 200, International Symposium on the Mineralogy, Petrology and Geochemistry of Granitic Pegmatites. Field trip guide book, Masyryk University, Brno Czechoslovakia

Klećka M, Vaňková V (1988) Geochemistry of felsitic dykes from the vicinity of Lásenice near Jindrichuv Hradrec (South Bohemia) and their relation to Sn-W mineralization. Čas Mineral Geol 33:225-249

Klećka M, Bendl J, Matejka D (1994) Rb-Sr dating of acid subvolcanic dyke rocks-final magmatic products of the Moldanubian Batholith. Mitt Österr Min Ges 139:66-68

Klomínský J, Jarchovský T, Rajpoot G (2010 a) Atlas of plutonic rocks and orthogneisses in the Bohemian Massif; Introduction; Technical Report TR-01-2010. Czech Geological Survey, Prague

Klomínský J, Jarchovský T, Rajpoot G (2010 b) Atlas of plutonic rocks and orthogneisses in the Bohemian Massif; 2. Moldanubicum. Technical Report TR-01-2010, Czech Geological Survey, Prague

Klötzli E, Klötzli U, Kosler J (2007) A possible laser ablation xenotime U-Pb age standard: reproducibility and accuracy. Geochim Acta 71:A495

Klötzli U, Klötzli E, Günes Z, Kosler J (2009) Accuracy of laser ablation $\mathrm{U}-\mathrm{Pb}$ zircon dating: results from a test using five different reference zircons. Geostandards Res Geoanal 33:5-15 
Koller F (1994) The South Bohemian Pluton-A complex batholith with a multiple intrusion history. Mitt Österr Min Ges 139:71-73

Le Bas MJ, Le Maitre RW, Streckeisen A, Zanettin B (1986) A chemical classification of volcanic rocks based on the total alkali-silica diagram. J Petrol 27:745-750

Le Maitre RW (2002) Igneous rocks - a classification and glossary of terms; Cambridge University Press

Ludwig KR (2003) User's manual for isoplot/Ex version 3.00, a geochronological toolkit for Microsoft Excel. Berkeley Geochronology Center Special Publications, 4

Moore DM, Reynolds RC Jr (1997) X-ray diffraction and the identification and analysis of clay minerals, 2nd edn. Oxford University Press, New York

Pirajno F (2009) Hydrothermal processes and mineral systems. Springer, Berlin

Scharbert HG (1957) Über Ganggesteine aus dem oberösterreichischen Mühlviertel (westlich der Rodelstörung). Neues Jahrb Mineral Abh 90:135-202

Schnabel W, Bryda G, Egger H et al (2002) Geologische Karte von Niederösterreich 1:200.000. Geologische Bundesanstalt, Vienna

Schultz LG (1964) Quantitative interpretation of mineralogical composition from X-ray and chemical data for the Pierre Shale, Geol Surv Prof Paper 391, C, Washington

Seal RR II (2006) Sulphur isotope geochemistry of sulphide minerals. Rev Mineral Geochem 61:633-677

Seedorf E, Dilles JH, Profett J Jr, Einaudi MT (2005) Porphyry deposits: characteristics and origin of hypogene features. Econ Geol 100th Anniversary Volume, pp 251-298

Sillitoe RH (2010) Porphyry copper systems. Econ Geol 105:3-41
Sláma J, Kosler J, Condon DJ et al (2008) Plesovice zircon - a new natural reference material for $\mathrm{U}-\mathrm{Pb}$ and $\mathrm{Hf}$ isotopic microanalysis. Chem Geol 249:1-35

Spencer ET, Wilkinson JJ, Creaser RA, Seguel J (2015) The distribution and timing of molybdenite mineralization at the $\mathrm{El}$ Teniente $\mathrm{Cu}-\mathrm{Mo}$ porphyry deposit, Chile. Econ Geol 110:387-421

Sylvester PJ, Ghaderi M (1997) Trace element analysis of scheelite by excimer laser ablation-inductively coupled plasma-mass spectrometry (ELA-ICP-MS) using a synthetic silicate glass standard. Chem Geol 141:49-65

Thompson AJB, Thompson JFH (1996) Atlas of alteration - A field and petrographic guide to hydrothermal alteration minerals. Geol Assoc Can, Mineral Deposits Division

Vellmer C, Wedepohl KH (1994) Geochemical characterization and origin of granitoids from the South Bohemian Batholith in Lower Austria. Contrib Mineral Petrol 118:13-32

Vrána S (1990) The Pelhrimov volcanotectonic circular structure. Věstnik Ústredniho ustavo geologickeho 65:143-156

Waldmann L (1950) Geologische Spezialkarte der Republik Österreich. 1:75 000, Blatt Litschau-Gmünd (4454). Geologische Bundesanstalt, Vienna

Wedepohl KH (1995) The composition of the continental crust. Geochim Cosmochim Acta 59:1217-1232

Žak J, Verner K, Finger F, Wali Faryad S, Chlupáčová M, Veselovský F (2011) The generation of voluminous S-type granites in the Moldanubian unit, Bohemian Massif, by rapid isothermal exhumation of the metapelitic middle crust. Lithos 121:25-40

Zwicker W (1953) Beiträge zur Kenntnis moldanubischer Ganggesteine. Tschermaks Mineral Petrogr Mitt 3:356-375 